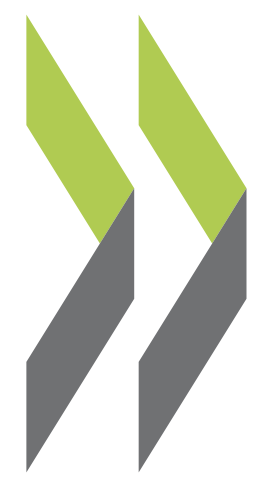

OECD Economics Department Working Papers No. 1061 Restructuring Welfare Spending in Slovenia

\title{
Rafal Kierzenkowski
}

https://dx.doi.org/10.1787/5k44v50kwzxx-en 


\section{Unclassified}

ECO/WKP(2013)53

Organisation de Coopération et de Développement Économiques

Organisation for Economic Co-operation and Development

14-Jun-2013

ECONOMICS DEPARTMENT

English - Or. English

\section{RESTRUCTURING WELFARE SPENDING IN SLOVENIA}

ECONOMICS DEPARTMENT WORKING PAPERS No. 1061

\section{By Rafał Kierzenkowski}

All Economics Department Working Papers are available on the OECD's Internet website at http://www.oecd.org/eco/Workingpapers

JT03341902

Complete document available on OLIS in its original format

This document and any map included herein are without prejudice to the status of or sovereignty over any territory, to the delimitation of international frontiers and boundaries and to the name of any territory, city or area. 


\section{ABSTRACT/RÉSUMÉ Restructuring welfare spending in Slovenia}

Restoring fiscal sustainability is a major challenge in Slovenia. Yet, the performance in terms of expenditure control is poor and public expenditure on social spending increased briskly during the crisis, significantly more than on average across the OECD. Despite recent progress in reforming the pension system, Slovenia continues to face major age-related spending pressures. Reforming the welfare state would help achieve fiscal consolidation, increase the quality of fiscal adjustment and address long-term fiscal sustainability challenges. This could be done without significantly worsening income inequality, which is low in Slovenia. Despite recent progress, cash transfers do not seem to be sufficiently means tested. Partly driven by generous social transfers, average effective tax rates on returning to work from inactivity and unemployment are high and could be further cut gradually. Efficiency frontier analysis suggests there is scope to improve spending efficiency without undermining the quality of in kind services on secondary education, health care and public administration. There is excess capacity in pre-school and compulsory education and the allocation of tertiary education services is regressive. The delivery of health care could be improved by rationalising inpatient care and enhancing costeffective primary care, which would generate savings in the medium term. Further increasing the effective retirement age and reforming the financing of health and long-term care are the main policy priorities to contain the pressure of population ageing on expenditure. This Working Paper relates to the 2013 OECD Economic Review of Slovenia (http://www.oecd.org/eco/surveys/slovenia-2013.htm).

JEL Classification: H62, I18, I28, I38, J14, J26, J65

Keywords: Slovenia, fiscal consolidation, sustainability, welfare spending, cash transfers, in-kind benefits, education, health, long-term care, pension system.

\section{Restructurer les dépenses sociales en Slovénie}

Restaurer la soutenabilité des finances publiques est un enjeu majeur en Slovénie. Cependant, la maîtrise des dépenses est faible et les dépenses sociales publiques ont fortement augmenté durant la crise - nettement plus qu'en moyenne dans la zone OCDE. En dépit de récentes avancées de la réforme du système de retraite, la Slovénie reste confrontée à de fortes pressions sur les dépenses liées au vieillissement de la population. Une réforme de l'État-providence contribuerait à l'assainissement budgétaire, améliorerait la qualité de l'ajustement budgétaire et relèverait les défis de soutenabilité des finances publiques à long terme. Cette réforme pourrait être menée sans détériorer significativement les inégalités de revenus, qui sont faibles en Slovénie. En dépit de progrès récents, les transferts monétaires ne semblent pas suffisamment soumis à des conditions de ressources. Alimentés en partie par de généreux transferts sociaux, les taux moyens effectifs d'imposition des inactifs et des chômeurs qui retrouvent un emploi sont élevés et pourraient être graduellement réduits. L'analyse des frontières d'efficience laisse entrevoir une marge d'amélioration de l'efficience des dépenses sans obérer pour autant la qualité des prestations en nature dans les domaines de l'enseignement secondaire, des soins de santé et de l'administration publique. Il existe des surcapacités dans l'enseignement préscolaire et obligatoire, et l'allocation des services de l'enseignement supérieur est régressive. La fourniture de soins de santé pourrait progresser en qualité grâce à une rationalisation des soins dispensés dans le cadre d'une hospitalisation et une meilleure efficacité-coût des soins primaires, ce qui engendrerait des économies à moyen terme. Un nouveau recul de l'âge effectif de la retraite et la réforme du financement des soins de santé et de la prise en charge de la dépendance sont les principales priorités de l'action publique afin de contenir la pression qu'exerce le vieillissement de la population sur les dépenses. Ce Document de travail se rapporte à l'Étude économique de l’OCDE de la Slovénie 2013 (http://www.oecd.org/fr/eco/etudes/slovenie-2013.htm)

Classification JEL : H62, I18, I28, I38, J14, J26, J65

Mots clefs: Slovénie, assainissement budgétaire, soutenabilité, dépenses sociales, transferts monétaires, prestations en nature, santé, soins de long terme, système de retraite.

You can copy, download or print OECD content for your own use, and you can include excerpts from OECD publications, databases and multimedia products in your own documents, presentations, blogs, websites and teaching materials, provided that suitable acknowledgment of OECD as source and copyright owner is given. All requests for commercial use and translation rights should be submitted to rights@oecd.org. 


\section{TABLE OF CONTENTS}

RESTRUCTURING WELFARE SPENDING IN SLOVENIA ......................................................... 5

Fiscal sustainability would benefit from a restructuring of welfare spending ........................................ 5

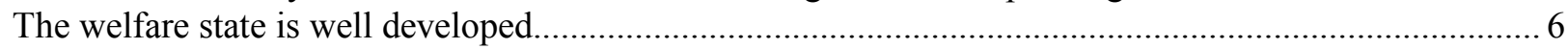

Public expenditure has increased briskly during the crisis.............................................................. 7

There is scope to reduce welfare spending while maintaining low inequality .................................... 10

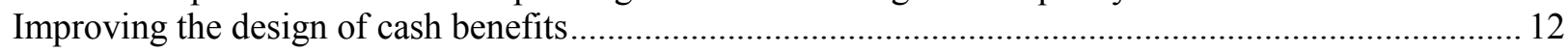

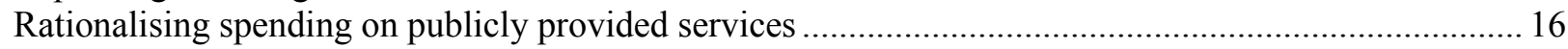

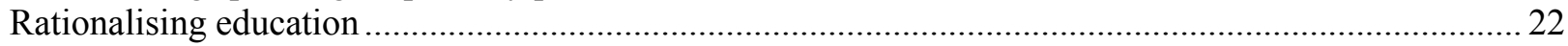

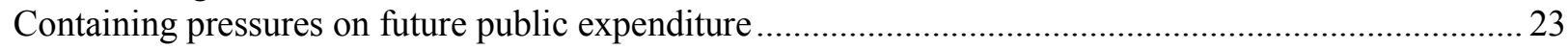

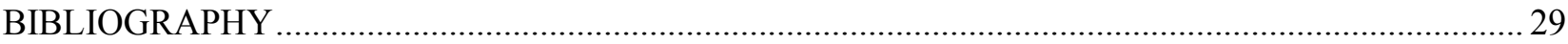

\section{Boxes}

Box 1. Recent reform of the system of social transfers and subsidies .................................................. 16

Box 2. Efficiency of welfare spending through the lens of efficiency frontier analysis .......................... 17

Box 3. Policy recommendations to restructure welfare spending .......................................................... 28

\section{Tables}

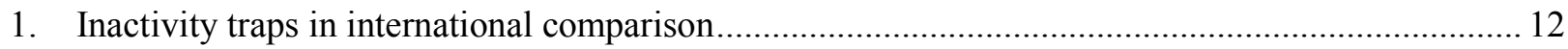

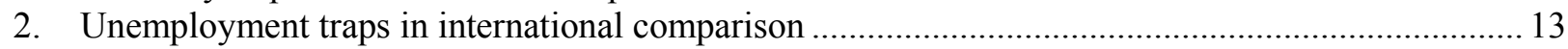

3. Net replacement rates during unemployment in international comparison..................................... 15

4. Average length of stay in inpatient and acute care for selected diagnostic categories.......................20

\section{Figures}

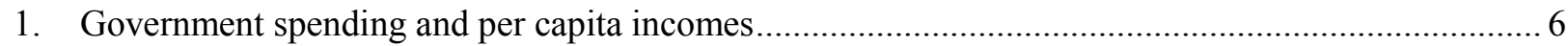

2. Public expenditure on cash transfers to households and in-kind benefits ........................................ 7

3. Evolution of public expenditure by main component .................................................................... 8

4. Breakdown of total government expenditure during fiscal policy phases ........................................ 9

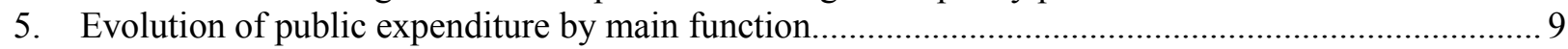

6. Gini coefficients of inequality of market and disposable incomes .............................................. 10

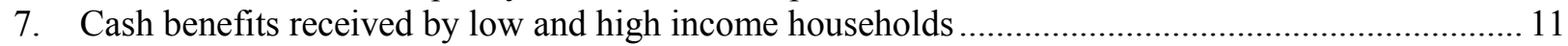

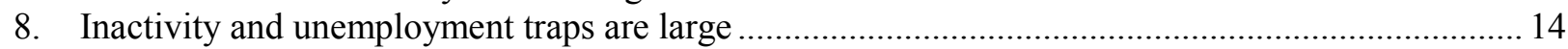

9. The relationship between health spending and per capita incomes............................................... 18

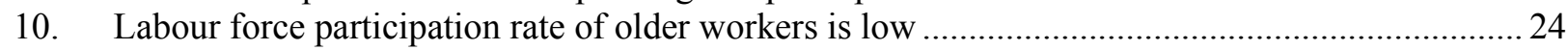

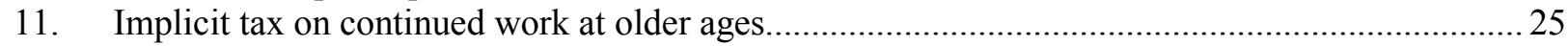

The statistical data for Israel are supplied by and under the responsibility of the relevant Israeli authorities. The use of such data by the OECD is without prejudice to the status of the Golan Heights, East Jerusalem and Israeli settlements in the West Bank under the terms of international law 
ECO/WKP(2013)53 
ECO/WKP(2013)53

\title{
Restructuring Welfare Spending in Slovenia
}

By

\author{
Rafał Kierzenkowski ${ }^{1}$
}

\section{Fiscal sustainability would benefit from a restructuring of welfare spending}

Public expenditure as a share of gross domestic product (GDP) is close to 50\% in Slovenia and is now the highest among countries with similar levels of economic development (Figure 1, Panel A). The level of spending on social transfers and benefits in kind is close to $20 \%$ of GDP, against around $17 \%$ for the OECD and other Central and Eastern European countries (CEEC) and 18\% for the Nordic countries. Compensation of employees amounts to almost $13 \%$ of GDP in comparison with $9 \%$ for other CEECs and close to $11 \%$ for the OECD. While this situation may reflect social preferences for a well developed welfare state and policies aimed to cushion the impact of the crisis, it has also been driven by poor expenditure control as spending per capita is also sizeable relative to the level of economic development (Figure 1, Panel B). With no policy changes, public debt is projected to reach $87 \%$ of GDP in 2025 (European Commission, 2012a) and could exceed 100\% of GDP when including the costs of rescuing banks. Moreover, Slovenia faces a significant rise in total age-related public expenditure (which includes pensions, health and long-term care) by about 10 percentage points of GDP over the years 2010-60, against around 3 percentage points of GDP for the EU average (European Commission, 2012b), and the recent pension reform will only slightly contain pressure on spending.

Restructuring welfare spending would help to tackle the budget deficit and mitigate further increases in public spending driven by population ageing. Revisiting the welfare state would not induce excessive trade-offs with work incentives and equity objectives. At the same time, it would also expand the elbow room to amend the structure of expenditure in favour of growth-enhancing measures such as productive public investment or spending on active labour market policies.

1. The paper was prepared when the author was Head of Hungary/Slovenia Desk at the OECD (rafal.kierzenkowski@oecd.org). This working paper was originally published as Chapter 2 of the 2012 OECD Economic Survey of Slovenia, published under the authority of the Economic and Development Review Committee (EDRC). The author is grateful to Pierre Beynet, Andrew Dean, Robert Ford, and other OECD colleagues for helpful discussions, comments and suggestions, as well as Desney Erb for statistical assistance. 
Figure 1. Government spending and per capita incomes ${ }^{1}$ $2011^{2}$
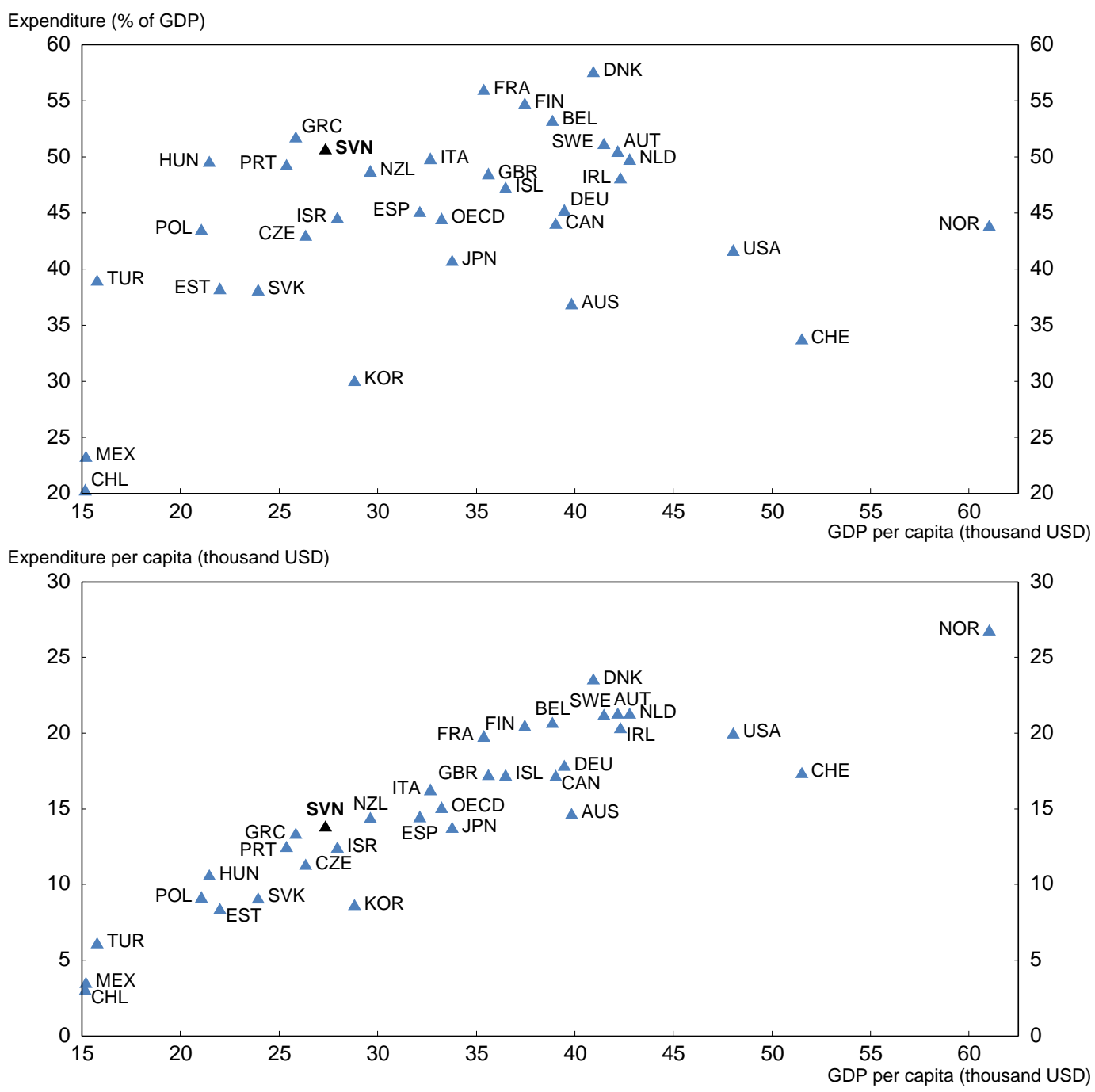

1. Total general government expenditure. Data in US dollars is calculated using current purchasing power parities. The OECD aggregate is an unweighted average of data shown.

2. 2009 for Australia and Chile; 2010 for Canada, Japan, Korea, Mexico, New Zealand and Turkey.

Source: OECD (2013), OECD National Accounts Statistics (database), February.

\section{The welfare state is well developed}

Cash transfers and in-kind (or publicly provided) services or benefits are a significant dimension of the welfare state in Slovenia. Before the global economic and financial crisis, when public spending increased markedly (see below), cash transfers on old-age, family, unemployment, incapacity and other policy areas amounted to $13.5 \%$ of GDP against an OECD average of 11\% in 2007 (Figure 2, Panel A). 
Pensions accounted for the bulk of total transfers and were two percentage points of GDP higher than the average across the OECD. At the same time, spending as a share of GDP on publicly provided education and health was predominant among in-kind services and very close to the OECD average (Figure 2, Panel B). On the other hand, public outlays on family services and other social areas were slightly less generous. Also, in-kind services to the elderly were underdeveloped.

Figure 2. Public expenditure on cash transfers to households and in-kind benefits

Per cent of GDP, $2007^{1}$
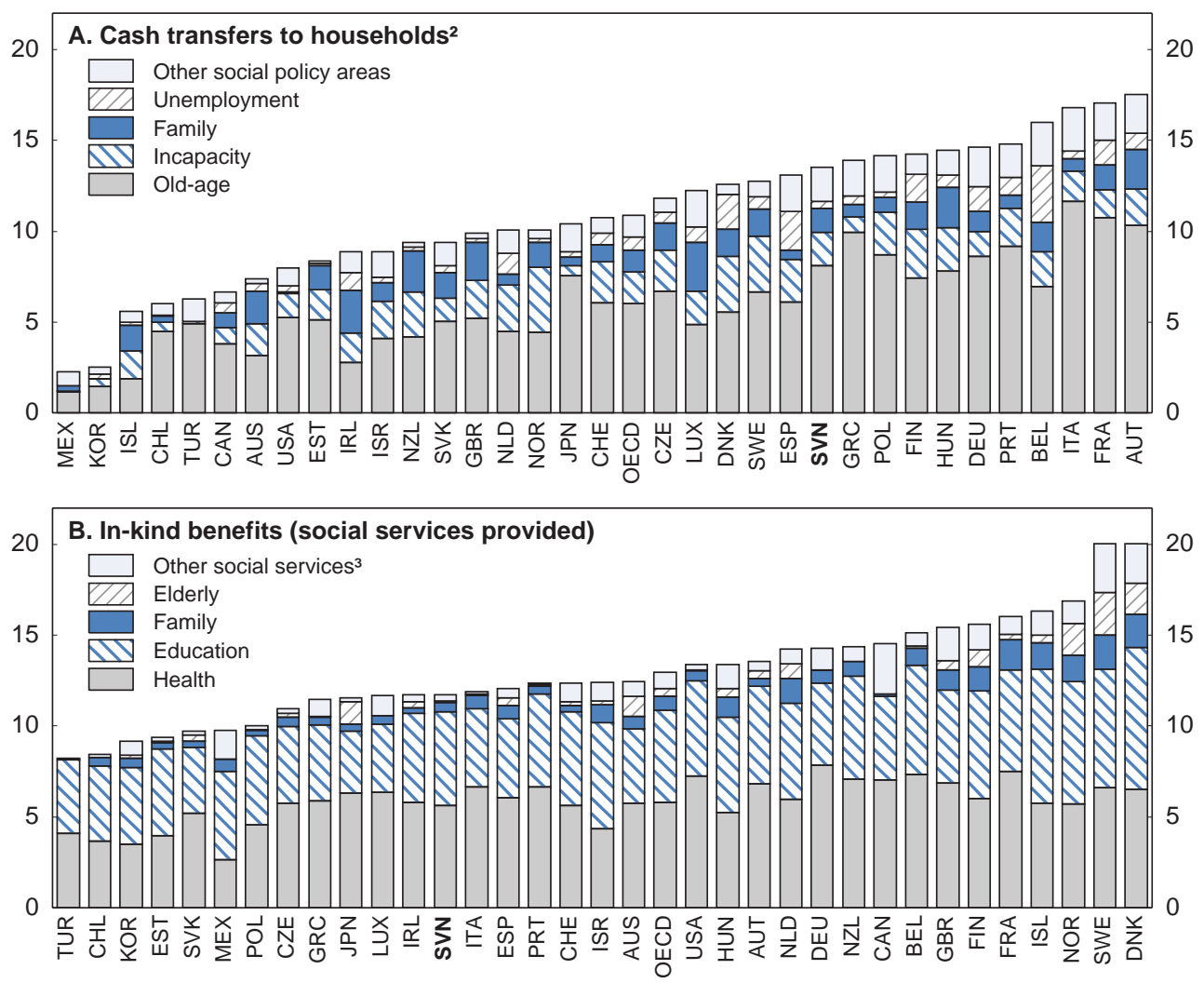

1. Data on education services for Greece, Luxembourg and Turkey refer to 2005. The OECD aggregate is an unweighted average.

2. The data shown exclude private mandatory spending which accounts for an important share of total social spending in some countries (in particular Chile, Germany and Switzerland). In addition, public cash transfers shown here may not fully account for those programmes and services provided, or co-financed, by local governments. Measurement gaps may be high, notably in federal countries such as Canada. Incapacity-related spending covers expenditure on disability pensions and sick leave schemes (occupational injury and other sickness daily allowances).

3. Services to survivors, disabled persons, unemployed, as well as those in respect of housing and social assistance (estimates of social housing are, however, not included).

Source: OECD (2012), OECD Social Expenditure Statistics (database), November and OECD (2011), Divided We Stand: Why Inequality Keeps Rising.

\section{Public expenditure has increased briskly during the crisis}

The share of public expenditure in GDP has increased markedly since the beginning of the crisis, worsening fiscal sustainability. General government outlays rose by nearly 8.5 percentage points of GDP during 2007-11, mainly driven by social benefits and transfers in kind, compensation of employees, and other expenditure, while capital expenditures and subsidies were cut (Figure 3, Panel A). This contrasts with more contained spending increases as a share of GDP in other OECD countries. In particular, spending on social benefits and transfers in kind increased markedly by 3.5 percentage points of GDP 
while the corresponding increases in percentage points were 1.5 for other CEEC, 1.9 for the Nordic countries and 2.2 for the OECD on average. At the same time, the increase in the compensation of employees by 2.2 percentage points of GDP was the highest in the OECD. Part of the difference is accounted for by more subdued growth in Slovenia, but it also relates to a poor performance of Slovenia in terms of expenditure control. Indeed, even expressed per capita and at constant purchasing power parities (PPP), the increase in overall government spending has been significantly higher than in Germany and on average across the OECD and other CEEC economies since the outset of the crisis (Figure 3, Panel B). The rise in the compensation of employees and the decline in gross fixed capital formation were among the highest. This reflects a composition of public spending, which is strongly skewed towards non discretionary components that reduce fiscal flexibility (Mattina and Gunnarsson, 2007).

Recent spending developments in Slovenia contrast with the past experience as growth in expenditure as a share of GDP was tightly under control in the pre-European monetary union (EMU) phase and shrinking in the qualifying period (Figure 4). Yet it increased significantly in the wake of the euro area membership, due to offsetting increases in expenditure, and the onset of the crisis which was marked by a deep decline in GDP by almost 8 percentage points in 2009. The share of public spending in GDP continued to grow at a sizeable pace in 2010 and 2011, despite a consolidation programme.

Figure 3. Evolution of public expenditure by main component

Change between 2007 and $2011^{1}$
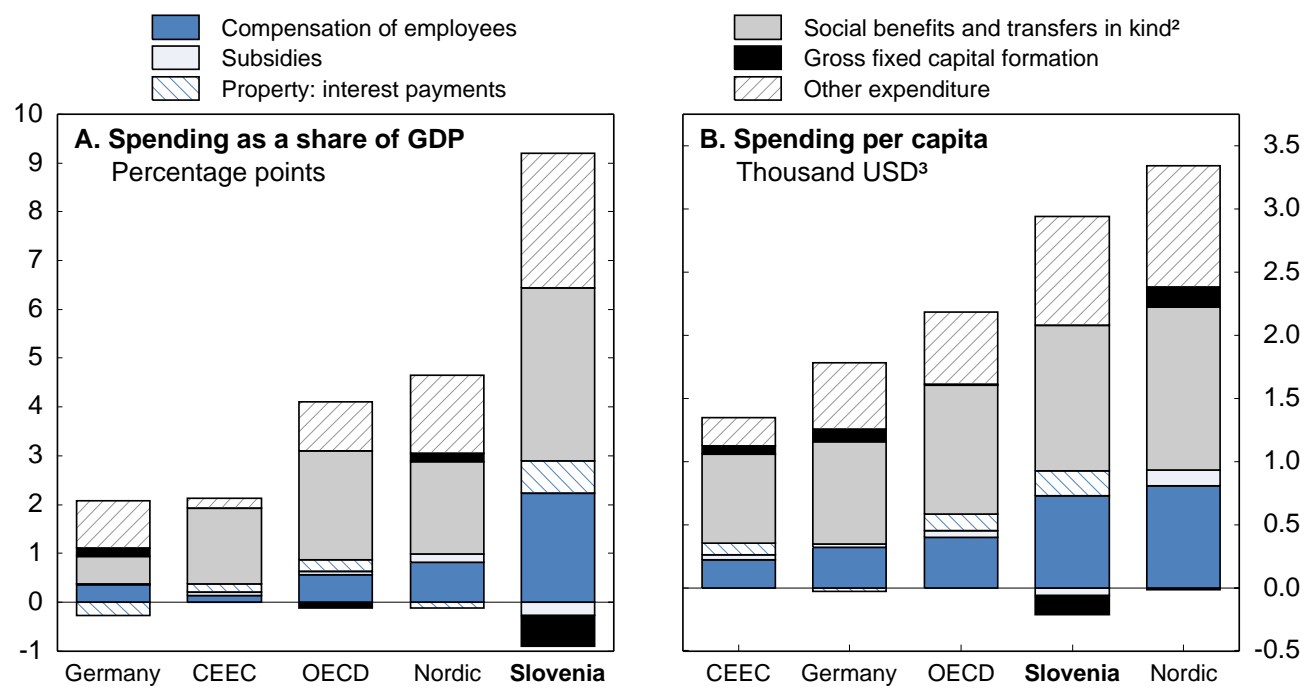

1. Total general government expenditure. All aggregates are unweighted averages; Central and Eastern European Countries (CEEC) excludes Slovenia. The OECD aggregate excludes Australia and Chile (no data available) and the calculations use estimates for six countries in 2011.

2. For products supplied to households via market suppliers.

3. Using constant purchasing power parities for GDP.

Source: OECD (2013), OECD National Accounts Statistics (database), February. 
Figure 4. Breakdown of total government expenditure during fiscal policy phases ${ }^{1}$

Average of annual rates of change over the period, percentage points of GDP

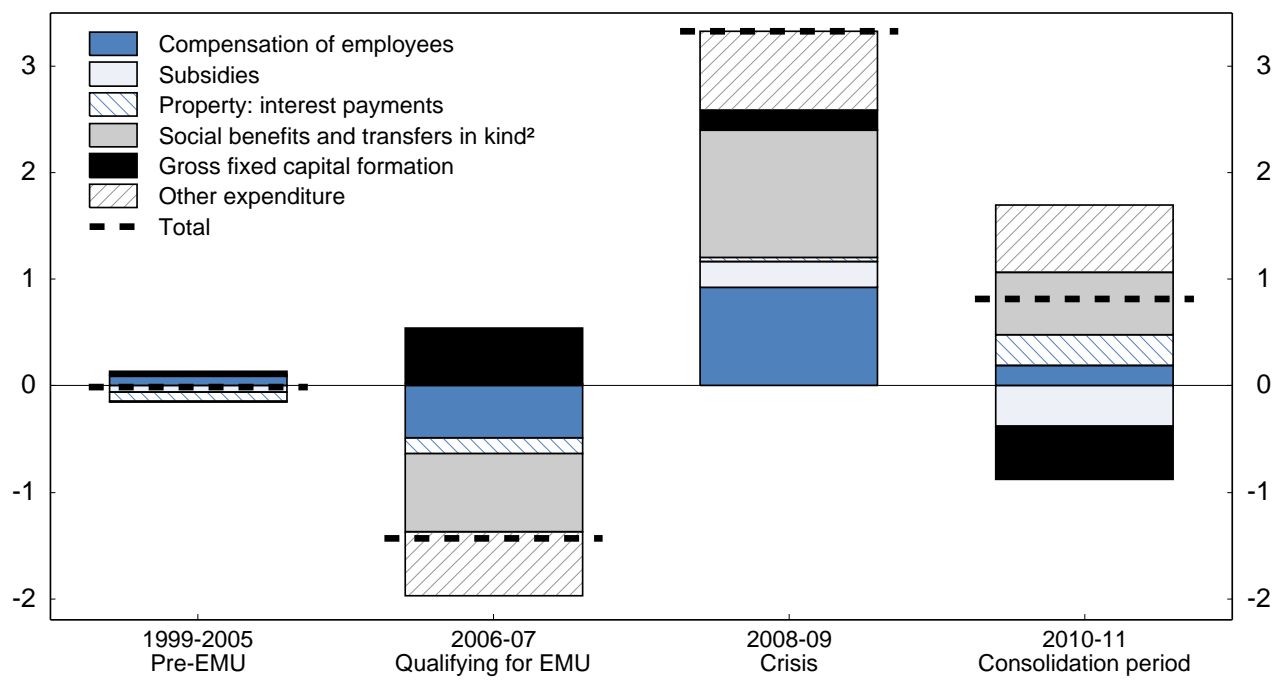

1. Based on national accounts definition. EMU: Economic and Monetary Union.

2. For products supplied to households via market suppliers.

Source: OECD (2013), OECD National Accounts Statistics (database), February.

A breakdown of general government expenditure by the main functions shows that, while increases in public spending on public services and safety appeared broadly comparable to other countries between 2007 and 2010 (latest available year), the growth in outlays on other expenditure and on social protection and health was relatively high (Figure 5, Panel A). The rise in government expenditure was also significant when considering spending per capita at constant PPP (Figure 5, Panel B).

\section{Figure 5. Evolution of public expenditure by main function}

Change between 2007 and $2010^{1}$
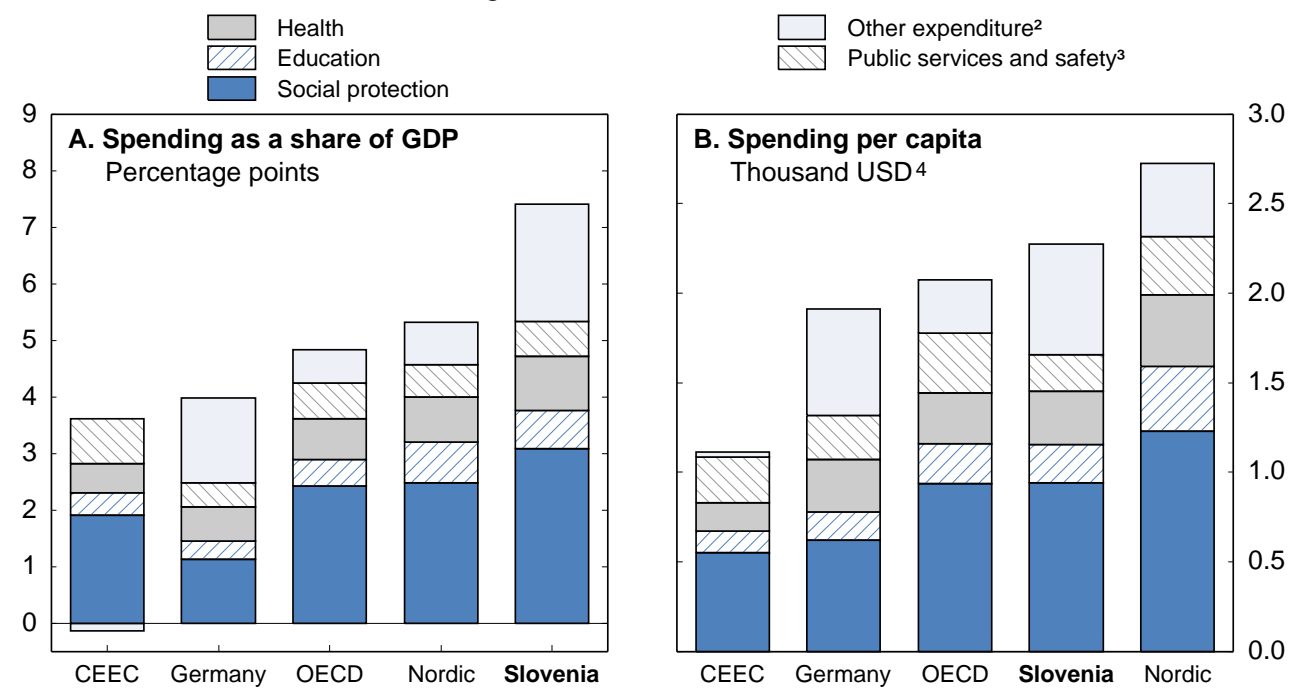

1. Total general government expenditure. All aggregates are unweighted averages; Central and Eastern European Countries (CEEC) excludes Slovenia and OECD excludes Australia, Canada, Chile, Mexico, New Zealand and Switzerland, for which no data are available.

2. Economic affairs; environment protection; housing and community amenities; recreation, culture and religion.

3. General public services, defence, public order and safety.

4. Using constant purchasing power parities for GDP.

Source: OECD (2013), OECD National Accounts Statistics (database), February. 


\section{There is scope to reduce welfare spending while maintaining low inequality}

\section{Disposable income inequality is the lowest in the OECD}

Slovenia has the lowest disposable income inequality - i.e. the income after taking into account taxes and cash transfers - among OECD countries (Figure 6). This indicates a high degree of social cohesion, but also some room for manoeuvre in reducing the size of redistributive policies without leading to an unequal society. In fact, the relative difference between market income and disposable income inequality of the working age population is among the highest in the OECD countries. Yet, even before this sizeable amount of redistribution, Slovenia has one of the lowest levels of income inequality before taxes and cash transfers in the OECD (Figure 6). This indicates again scope in reducing the extent of the welfare state without compromising social cohesion. Moreover, recent OECD empirical evidence suggests that in-kind benefits contribute to further diminishing income inequality in Slovenia (OECD, 2011a). In particular, the incomeincreasing effect of early childhood education and care services is large for families with young children, the enrolment rate in public child care of children in lower-income households is relatively high and social housing is strongly targeted to the poorest individuals.

Figure 6. Gini coefficients of inequality of market and disposable incomes ${ }^{1}$

Persons of working age (18-65 years-old), late $2000 \mathrm{~s}^{2}$

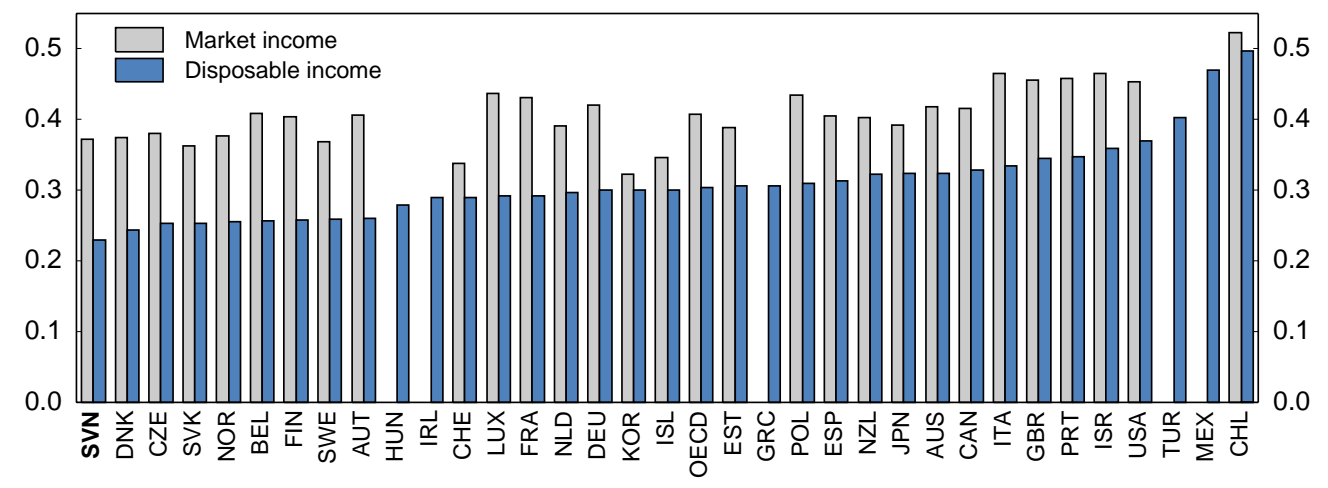

1. The Gini coefficient has a range from zero (when everybody has identical incomes) to 1 (when all income goes to only one person). Increasing values of the Gini coefficient thus indicate higher inequality in the distribution of income. Market income includes incomes from wages and salaries, self-employment income and cash property income together with occupational and private pensions. Disposable income is obtained by subtracting income tax and employees' social security contributions from gross income. Both income measures are adjusted to reflect differences in household needs depending on the number of persons in the household.

2. Late 2000s refers to a year between 2006 and 2009. The OECD average excludes Greece, Hungary, Ireland, Mexico and Turkey (no information on market income available).

Source: OECD (2011), Divided We Stand: Why Inequality Keeps Rising.

\section{Cash transfers and in-kind benefits have a low progressivity}

While the redistributive impact of household taxes is among the highest in the OECD and most of the redistribution occurs on the spending side, that of cash transfers is weakened by their relatively low progressivity (Joumard et al., 2012). The redistributive impact of public cash transfers is close to the OECD average, with their large size offsetting their lower progressivity. Sweden attains a stronger effect on inequality reduction due to higher progressivity of transfers, even though their magnitude is similar to that in Slovenia. Alternatively, Netherlands obtains about the same decrease in income dispersion as Slovenia through a combination of higher progressivity and a lower size of transfers. 
The redistributive impact of welfare benefits also depends on their mix, which in Slovenia is skewed towards pensions (Figure 2, Panel A). These are less progressive and the dispersion of pension transfers is quite high (Joumard et al., 2012), which is partly due to the characteristics of the pension system as people can retire at the age of 65 with 15 years of contributions only, hence weighing on the adequacy of pensions (see below). On the other hand, the progressivity of unemployment benefits, as measured by the difference in the net replacement for low and high earners (respectively at $67 \%$ and $150 \%$ of the average wage) is significantly above the OECD average, in particular for families with no children both in the initial phase and after five years of unemployment. Overall, while cash transfers are equivalent to $67 \%$ of market income of the poorest $20 \%$ in Slovenia, which is comparable to the OECD average, they are equivalent to $10 \%$ of high-income earners' market income (and essentially correspond to family benefits), which is quite significant in comparison with other OECD countries (Figure 7). Hence, the share of high-income earners eligible for cash transfers could be significantly reduced.Figure 7. Cash benefits received by low and high income households ${ }^{1}$

Per cent of market income, mid-2000s

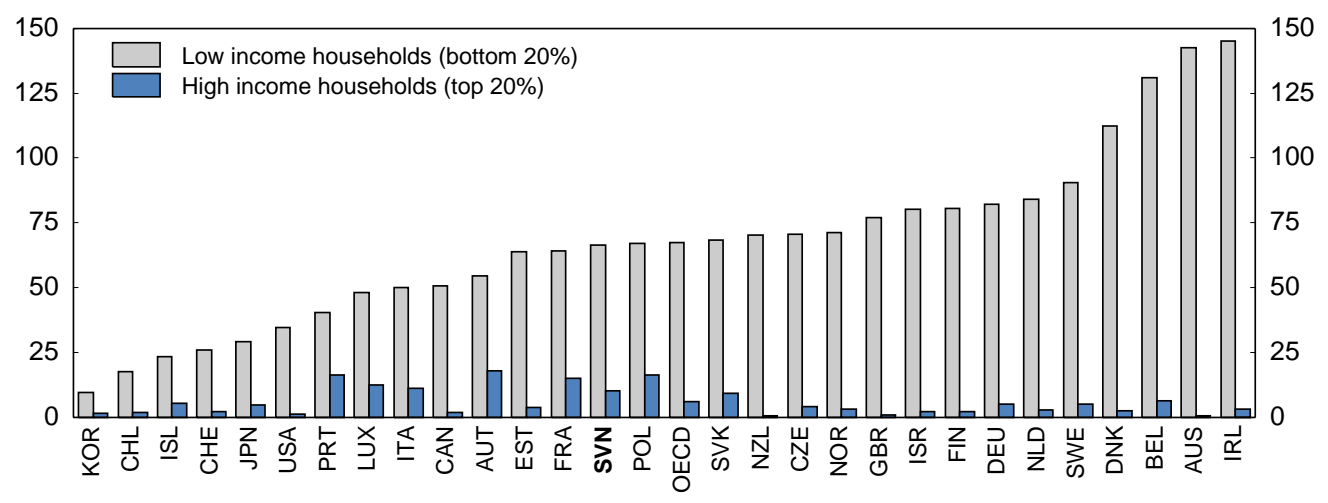

1. Households headed by working-age individuals.

Source: OECD (2011), Divided We Stand: Why Inequality Keeps Rising.

Better means testing would reduce the share of high-income earners eligible for cash transfers and boost fiscal savings. This would blunt work incentives because of correspondingly higher marginal effective tax rates when benefits are withdrawn, but empirical evidence suggests that the labour supply of high-income earners could remain unaffected at the hour-work margin (Meghir and Phillips, 2010). Moreover, additional savings could be reaped by means testing education-related allowances (transportation, student meals in tertiary education) and introducing stricter eligibility criteria (accommodation subsidies, state scholarships). Important progress has been made in this direction more recently with the implementation of a new electronic system that allows more efficient income and wealth means testing of a wide range of social transfers and subsidies (see below).

Countries with similar levels of expenditure on publicly provided services tend to perform better in reducing inequalities than Slovenia (OECD, 2011a). Various income inequality indicators decrease by about $18 \%$ in Slovenia after taking into account in-kind benefits while, for comparable levels of expenditure, their reductions are in the range of $24-33 \%$ in Ireland, $18-32 \%$ in Italy, $20-25 \%$ in Luxembourg or $20-34 \%$ in Spain. In particular, the allocation of tertiary education services is very regressive with $35 \%$ of tertiary education expenditures going to the top quintile of the income distribution and only $9 \%$ to the lowest one. The experience of OECD countries shows that introducing universal tuition fees along with means-tested grants and loans with income-contingent repayments would promote access and equity while sharing the costs of higher education between the state and students (OECD, 2012). 


\section{Improving the design of cash benefits}

Despite recent progress, there is still scope to reduce public spending by cutting the combined generosity of cash benefits, such as unemployment benefits, social assistance and other social transfers for the unemployed and inactive persons. This would boost work incentives and even more so if, at low income levels, benefits could be withdrawn at a lower rate than the increase in earnings to allow a net increase in income. However, as such benefit reforms are likely to worsen income distribution, they should continue to be introduced gradually. Indeed, empirical research shows that they can have more favourable employment effects in good times rather in bad times (Bouis et al., 2012). That said, the political economy of reforms suggests that bad times tend to be a major driver of reforms and that such reforms should be legislated soon, even if their actual implementation is somehow delayed.

\section{Reducing welfare traps}

The level of average effective tax rates (AETRs) when returning to work from inactivity (or inactivity trap), which measures the proportion of any increase in earnings that is lost through the combined operation of different tax increases and withdrawal of benefits for inactive people no longer eligible for unemployment benefits, is high (Table 1; see also Stovicek and Turrini, 2012). For instance, 82\% of income is lost due to taxes and reduced benefits when moving from inactivity to employment for households consisting of a one-earner married couple with two children at $67 \%$ of average wage. The AETRs in Slovenia are significantly above 50\%, except for two-earner married couples with children. They are much higher than in other CEEC economies, but their magnitude is also large in comparison with the OECD average. On the benefit side, they are mainly driven by spending on social assistance and, to a smaller extent, housing and family benefits (Figure 8, Panel A).

Table 1. Inactivity traps in international comparison

Average effective tax rate when moving from inactivity into work for selected family types and earnings levels, per cent, $2010^{1}$

\begin{tabular}{|c|c|c|c|c|c|c|}
\hline Family type & $\begin{array}{c}\text { Wage level } \\
\text { (\% of average worker) }\end{array}$ & Slovenia & Germany & $\begin{array}{l}\text { Other } \\
\text { CEEC }^{2}\end{array}$ & $\begin{array}{c}\text { Nordic } \\
\text { countries }^{2}\end{array}$ & $\mathrm{OECD}^{2}$ \\
\hline \multirow[t]{3}{*}{ One-earner married couple } & 67 & 75 & 70 & 54 & 85 & 63 \\
\hline & 100 & 64 & 62 & 45 & 72 & 54 \\
\hline & 150 & 57 & 55 & 42 & 64 & 49 \\
\hline \multirow[t]{3}{*}{ Lone parent with two children } & 67 & 77 & 80 & 45 & 68 & 57 \\
\hline & 100 & 76 & 70 & 48 & 63 & 55 \\
\hline & 150 & 67 & 62 & 44 & 59 & 51 \\
\hline \multirow[t]{3}{*}{ One-earner married couple with two children } & 67 & 82 & 78 & 57 & 94 & 66 \\
\hline & 100 & 75 & 69 & 49 & 81 & 60 \\
\hline & 150 & 67 & 60 & 45 & 71 & 54 \\
\hline \multirow[t]{3}{*}{ Two-earner married couple with two children } & 67 & 52 & 48 & 30 & 40 & 35 \\
\hline & 100 & 49 & 48 & 30 & 39 & 36 \\
\hline & 150 & 48 & 47 & 31 & 42 & 37 \\
\hline
\end{tabular}

1. Average effective tax rates measure the extent to which taxes and benefits reduce the financial gain of moving into work. The estimates here relate to the situation of a person who is not entitled to unemployment benefits (e.g. because their entitlements have expired). Instead, social assistance and other means-tested benefits are assumed to be available subject to relevant income conditions. Where receipt of such assistance is subject to activity tests (such as active job-search or being "available" for work), these requirements are assumed to be met in the out-of-work situation. Cash housing benefits are calculated assuming private market rent, plus other charges, amounting to $20 \%$ of the full-time wage for all family types. The percentage of average worker (AW) relates to the earnings from full-time employment of the individual moving into work. For married couples the percentage of AW relates to one spouse only; the second spouse is assumed to be inactive with no earnings in a one-earner couple and to have full-time earnings equal to $67 \%$ of AW in a two-earner couple. Calculations for families with children assume two children aged 4 and 6 , neither childcare benefits nor childcare costs are considered.

2. Unweighted averages, the OECD aggregate excludes Chile and Mexico for which no data are available. CEEC: Central and Eastern European Countries.

Source: OECD (2012), Tax/Benefit models (see www.oecd.org/els/social/workincentives). 
For people who are also entitled to unemployment benefits, the AETRs measuring their implicit taxation (or unemployment traps) when they return to full-time work are also high in Slovenia (Table 2 and Figure 8, Panel B). They exceed $70 \%$ and tend to increase with income levels. They are systematically higher than in other CEEC countries and the OECD average. On a different measure which does not include the impact of taxes, the net replacement rates at the initial phase of unemployment for families that also qualify for additional financial "top ups" appear substantial, often above $80 \%$ (Table 3). They are significantly higher than in other countries apart from a few exceptions. The net replacement rates with additional "top ups" drop for long unemployment spells (Table 3). Yet their generosity still appears significant for families with children. The duration of unemployment benefits - of up to 25 months - is also relatively generous.

Table 2. Unemployment traps in international comparison

Average effective tax rate for a transition into full-time work for persons receiving unemployment benefits at the initial level, for selected family types and earnings levels (same in new job as in previous), per cent, $2010^{1}$

\begin{tabular}{lcccccc}
\hline \multicolumn{1}{c}{ Family type } & $\begin{array}{c}\text { Wage level } \\
\text { (\% of average worker) }\end{array}$ & Slovenia & Germany & $\begin{array}{c}\text { Other } \\
\text { CEEC }\end{array}$ & $\begin{array}{c}\text { Nordic } \\
\text { countries }^{2}\end{array}$ & OECD $^{2}$ \\
\hline One-earner married couple & 67 & 80 & 69 & 63 & 77 & 70 \\
& 100 & 81 & 73 & 59 & 69 & 65 \\
Lone parent with two children & 150 & 69 & 74 & 55 & 63 & 59 \\
& 67 & 77 & 77 & 69 & 81 & 70 \\
One-earner married couple with two children & 100 & 87 & 80 & 69 & 73 & 69 \\
& 150 & 75 & 79 & 61 & 66 & 63 \\
Two-earner married couple with two children & 67 & 80 & 74 & 61 & 78 & 69 \\
& 100 & 79 & 77 & 59 & 70 & 67 \\
& 150 & 71 & 78 & 54 & 64 & 61 \\
& 67 & 87 & 86 & 69 & 78 & 70 \\
\end{tabular}

1. Average effective tax rates measure the extent to which taxes and benefits reduce the financial gain of moving into work. The estimates here relate to the situation of a person who has just become unemployed and receives unemployment benefits (following any waiting period) based on previous earnings equal to earnings in the new job. No social assistance "top-ups" or cash housing assistance are assumed to be available in either the in-work or out-of-work situation. Any benefits payable on moving into employment are assumed to be paid. The percentage of average worker (AW) relates to the earnings from full-time employment of the individual moving into work. For married couples the percentage of AW relates to one spouse only; the second spouse is assumed to be inactive with no earnings in a one-earner couple and to have full-time earnings equal to $67 \%$ of AW in a twoearner couple. Calculations for families with children assume two children aged 4 and 6 , neither childcare benefits nor childcare costs are considered.

2. Unweighted averages, the OECD aggregate excludes Chile and Mexico for which no data are available. CEEC: Central and Eastern European Countries.

Source: OECD (2012), Tax/Benefit models (see www.oecd.org/els/social/workincentives). 
Figure 8. Inactivity and unemployment traps are large

Average effective tax rate, $2010^{1}$

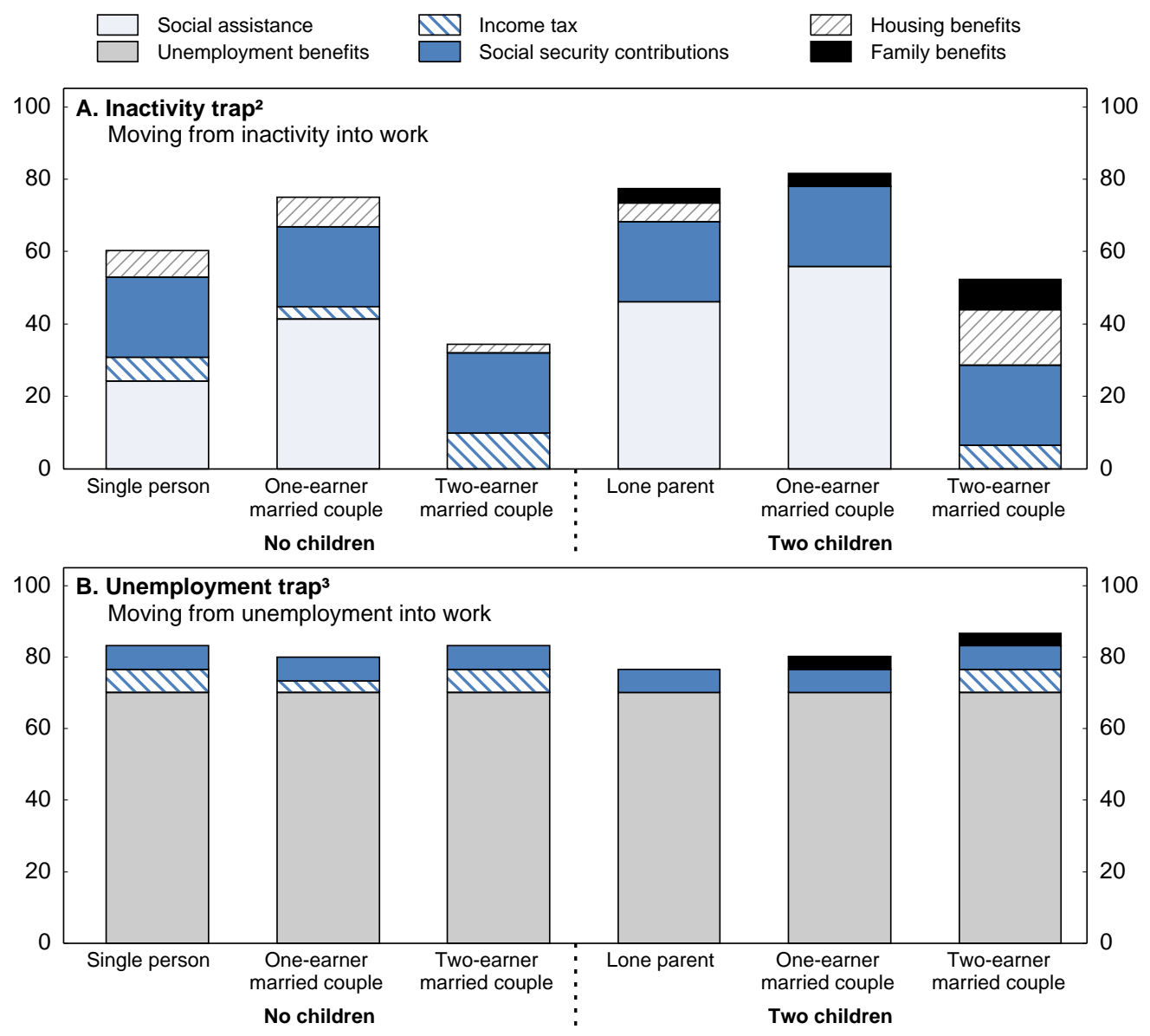

1. Average effective tax rates measure the extent to which taxes and benefits reduce the financial gain of moving into work. The percentage of average worker (AW) relates to the earnings from full-time employment of the individual moving into work based on $67 \%$ of the AW level. For married couples the percentage of AW relates to one spouse only; the second spouse is assumed to be inactive with no earnings in a one-earner couple and to have full-time earnings equal to $67 \%$ of AW in a two-earner couple. Calculations for families with children assume two children aged 4 and 6; neither childcare benefits nor childcare costs are considered. Any benefits received are subject to relevant income conditions or means-testing.

2. For full details of coverage see footnotes of Table 1.

3. Unemployment at the initial level; for full details of coverage see footnotes of Table 2.

Source: OECD (2012), Tax/Benefit models (see www.oecd.org/els/social/workincentives). 
ECO/WKP(2013)53

Table 3. Net replacement rates during unemployment in international comparison

For selected family types and earnings levels, per cent, $2010^{1}$

\begin{tabular}{|c|c|c|c|c|c|c|c|}
\hline & Family type & $\begin{array}{c}\text { Wage level } \\
\text { (\% of average worker) }\end{array}$ & Slovenia & Germany & $\begin{array}{l}\text { Other } \\
\text { CEEC }\end{array}$ & $\begin{array}{c}\text { Nordic } \\
\text { countries }^{2}\end{array}$ & $\mathrm{OECD}^{2}$ \\
\hline \multirow{12}{*}{$\begin{array}{l}\text { Initial phase of } \\
\text { unemployment }{ }^{3}\end{array}$} & \multirow{3}{*}{$\begin{array}{l}\text { One-earner married } \\
\text { couple }\end{array}$} & 67 & 85 & 61 & 69 & 81 & 74 \\
\hline & & 100 & 74 & 61 & 59 & 64 & 62 \\
\hline & & 150 & 53 & 60 & 49 & 48 & 49 \\
\hline & \multirow{3}{*}{$\begin{array}{l}\text { Lone parent with two } \\
\text { children }\end{array}$} & 67 & 83 & 76 & 79 & 87 & 77 \\
\hline & & 100 & 89 & 72 & 73 & 75 & 71 \\
\hline & & 150 & 68 & 69 & 60 & 59 & 57 \\
\hline & \multirow{3}{*}{$\begin{array}{l}\text { One-earner married } \\
\text { couple with two children }\end{array}$} & 67 & 84 & 77 & 70 & 93 & 78 \\
\hline & & 100 & 89 & 75 & 61 & 76 & 71 \\
\hline & & 150 & 71 & 70 & 52 & 59 & 56 \\
\hline & \multirow{3}{*}{$\begin{array}{l}\text { Two-earner married } \\
\text { couple with two children }\end{array}$} & 67 & 92 & 90 & 85 & 87 & 85 \\
\hline & & 100 & 86 & 88 & 77 & 76 & 77 \\
\hline & & 150 & 71 & 83 & 68 & 64 & 66 \\
\hline \multirow{12}{*}{$\begin{array}{l}\text { Long-term } \\
\text { unemployment }{ }^{4}\end{array}$} & \multirow{3}{*}{$\begin{array}{l}\text { One-earner married } \\
\text { couple }\end{array}$} & 67 & 67 & 61 & 46 & 71 & 56 \\
\hline & & 100 & 49 & 45 & 32 & 53 & 41 \\
\hline & & 150 & 35 & 31 & 23 & 39 & 29 \\
\hline & \multirow{3}{*}{$\begin{array}{l}\text { Lone parent with two } \\
\text { children }\end{array}$} & 67 & 79 & 76 & 51 & 71 & 59 \\
\hline & & 100 & 70 & 58 & 41 & 59 & 49 \\
\hline & & 150 & 54 & 42 & 29 & 46 & 37 \\
\hline & \multirow{3}{*}{$\begin{array}{l}\text { One-earner married } \\
\text { couple with two children }\end{array}$} & 67 & 84 & 77 & 58 & 85 & 66 \\
\hline & & 100 & 72 & 62 & 44 & 68 & 53 \\
\hline & & 150 & 57 & 45 & 32 & 52 & 40 \\
\hline & \multirow{3}{*}{$\begin{array}{l}\text { Two-earner married } \\
\text { couple with two children }\end{array}$} & 67 & 71 & 65 & 59 & 65 & 62 \\
\hline & & 100 & 60 & 55 & 49 & 54 & 53 \\
\hline & & 150 & 50 & 44 & 39 & 45 & 43 \\
\hline
\end{tabular}

1. For married couples the percentage of average worker (AW) relates to the previous earnings of the "unemployed" spouse only; the second spouse is assumed to be "inactive" with no earnings and no recent employment history. Where receipt of social assistance or other minimum-income benefits is subject to activity tests (such as active job-search or being "available" for work), these requirements are assumed to be met. Children are aged 4 and 6 and neither childcare benefits nor childcare costs are considered.

2. Unweighted averages, the OECD aggregate excludes Chile and Mexico for which no data are available.

3. Initial phase of unemployment but following any waiting period. After tax and including unemployment and family benefits; social assistance and other means-tested benefits are assumed to be available subject to relevant income conditions. Housing costs are assumed equal to $20 \%$ of AW. Any income taxes payable on unemployment benefits are determined in relation to annualised benefit values (i.e. monthly values multiplied by 2) even if the maximum benefit duration is shorter than 12 months.

4. After tax and including unemployment benefits, social assistance, family and housing benefits in the 60th month of benefit receipt.

Source: OECD (2012), Tax/Benefit models (see www.oecd.org/els/social/workincentives).

\section{Recent reforms of social transfers and subsidies}

Recent reforms of social benefits create a strong potential to boost fiscal savings. Major progress has been achieved with the implementation, since January 2012, of a new electronic system with a central database that allows an efficient income and wealth means testing of social transfers and subsidies, which bodes well for a rationalisation of welfare expenditure (Box 1; see also Kump et al., 2011 and Stropnik, 2011). Preliminary results indicate that the system is effective and has lowered eligibility of high-income earners to social transfers through tighter means testing and reduced fraud through better access to information. However, there were plans to increase the minimum income by $25 \%$ prior to the implementation of the new system, which is used as a base for social assistance. This would have strained public expenditure and deepened benefit dependency so that eventually the magnitude of the hike was reduced by half. 


\section{Box 1. Recent reform of the system of social transfers and subsidies}

A new reform, adopted in July 2010 and implemented since January 2012, introduces major changes in the access to and delivery of means tested social transfers and subsidies. The main objectives of the reform are:

- More transparent, efficient and user-friendly distribution of benefits with the creation of a unified information system, one-stop shops, single application form, and a single decision about all rights.

- Harmonisation of eligibility criteria for four types of social transfers and nine types of subsidies.

- Improved targeting to those most in need of support with means tests for income and wealth.

The reform establishes a priority order for exercising individual rights, while eligibility is conditional on an income threshold including all types of incomes and benefits, except those granted for a special purpose or intended to cover special needs. As a result, the new system prevents an excessive accumulation of benefits. Wealth is also taken into consideration, including the value of immovable property above a certain threshold, vehicles, vessels, bonds, shares, cash, bank deposits, savings on other bank accounts and other types of movable property. It is expected that stricter eligibility conditions and a lower likelihood of fraud through electronic cross-checking of information (with access to more than 40 official databases from 24 institutions) could reduce the number of beneficiaries by $10 \%$. Moreover, the benefit take-up rate could also be lowered because of an old regulation dating back to the 1970s, requiring the repayment of financial assistance after death from inheritance assuming that this does not endanger the social security of heirs, which could now be enforced more strictly.

Source: Ministry of Labour, Family and Social Affairs.

Fiscal consolidation measures adopted in the first half of 2012 somewhat reduced the generosity of social transfers. Subsidies for school and student meals were lowered, parents were required to cover $30 \%$ of childcare costs for the second child, the parental benefit for child care and nursing was cut, the indexation of child benefits was frozen and eligibility conditions were tightened for higher-income earners. The generosity of unemployment benefits was also somewhat decreased. The replacement rate was reduced from $60 \%$ to $50 \%$ for spells longer than a year, but left unchanged at $80 \%$ for the first three months and $60 \%$ for jobless spells between four and twelve months. Also, the ceiling for the highest benefit amount was lowered by $15 \%$.

The unemployment benefit coverage is narrow, with only a third of jobless people receiving unemployment benefits, owing to strict contribution requirements depending on the duration of work experience, which nevertheless have been somewhat relaxed recently. Those excluded get less attention in terms of job counselling and activation, even though they can draw on other substantial forms of income support, in particular social assistance (OECD, 2009a; Stovicek and Turrini, 2012). Beyond streamlining administrative costs and despite the introduction of life-long career guidance in the Employment Service of Slovenia and recent coordination progress with the Centres for Social Work, merging the two institutions would create a level playing field between the unemployed and ensure their equal access to active labour market policies. More generally, resources devoted to training and job search services should be sheltered from ongoing fiscal consolidation efforts to support employment and ensure that the long-term unemployed remain attached to the labour market. Indeed, half of the unemployed have been searching for a job for more than a year and there have been growing labour market mismatches.

\section{Rationalising spending on publicly provided services}

In addition to restructuring cash transfers, public spending could be reduced by closing efficiency gaps in the provision of publicly provided services (Box 2). There is a significant potential to either strengthen output efficiency (achieve better outcomes for the same level of expenditure) or input efficiency (reduce spending for the same outcomes). The calculation of efficiency frontiers reveals relatively poor scores in comparison with other OECD countries. Slovenia never belongs to the group of best-performing OECD countries and ranks about 22nd in terms of input and output efficiency measures for the three areas of secondary education, health care and public administration. 


\section{Box 2. Efficiency of welfare spending through the lens of efficiency frontier analysis}

The calculation of an efficiency frontier using a cross-country technique called Data Envelopment Analysis (DEA) helps to identify to what extent equivalent outcomes could be achieved with less spending (input efficiency) or, alternatively, better outcomes could be reached with the same level of expenditure (output efficiency). The estimates are derived from model specifications established in earlier OECD empirical studies on health care (OECD, 2010), secondary education (Schwellnus, 2009) and public administration (Forthun and Hagemann, 2010). *

The output efficiency of health expenditure per capita, defined as potential gains in the number of years of life expectancy at birth stemming from a more efficient use of available resources, amounts to around two and a half years. Out of 34 OECD countries, Slovenia ranks 26th and its efficiency score is close to the OECD average and higher than for other Central and Eastern European countries (CEEC). However, at broadly similar income levels, Slovenia's performance is significantly lower than that of Israel and Korea and, to a smaller extent, New Zealand. Regarding input efficiency, Slovenia is ranked 25th and lags behind the OECD average and countries with comparable living standards, though its score is very close to that of the Czech Republic and higher than that for the Slovak Republic. There is scope to reduce health expenditure by nearly $1.5 \%$ of GDP in 2020 by exploiting efficiency gains relative to a projected trend increase in expenditure at the same pace as between 2000 and 2010 . Put differently, only a very limited increase in spending per capita would be needed from 2010 to 2020 to sustain the same gains in life expectancy as over the previous ten years if potential efficiency gains were to be exploited.

When considering expenditure per capita for the input variable and the average of PISA scores for the outcome variable (PISA: Programme for International Student Assessment), the efficiency of secondary education is significantly lower than in other CEEC countries and below the OECD average both in terms of output and input efficiency. In comparison with 34 OECD countries, Slovenia ranks 26 th for the former and 18th for the latter. The country could raise its synthetic PISA score by almost 46 points at the current level of education spending if resources were to be used more efficiently. Alternatively, it could cut spending per student by almost $45 \%$ while preserving the same PISA score if efficiency gains were to be reaped.

There are also efficiency gaps in the provision of public administration, defined as spending per capita on general public services and public order and safety, assessed against indicators of the quality of justice, the level of corruption (taken from the Global Competitiveness Report 2012-2013 [WEF, 2012]), and the level of regulatory burdens (as proxied by the OECD's index of Product Market Regulation). Slovenia's public administration appears to be quite inefficient among OECD countries. Out of a sample of 29 countries, it ranks 24th on output efficiency and 19th on input efficiency. Yet the efficiency scores of some other CEEC countries, for instance Hungary or the Slovak Republic, are even lower. However, caution is needed when interpreting these results as some of the input variables used in the analysis are soft (survey-based) indicators, which can be influenced by cyclical developments among others.

* References: C. Forthun, and R. Hagemann (2010), "Sustaining the Momentum of Fiscal Reform in Hungary", OECD Economics Department Working Papers, No. 802; OECD (2010), Health Care Systems: Efficiency and Policy Settings; C. Schwellnus, (2009), "Achieving Higher Performance: Enhancing Spending Efficiency in Health and Education in Mexico", OECD Economics Department Working Papers, No. 732; and WEF (2012), Global Competitiveness Report 2012-2013, World Economic Forum.

Source: M. Hribernik and R. Kierzenkowski (2013), "Assessing the Efficiency of Welfare Expenditure in Slovenia with Data Envelopment Analysis", OECD Economics Department Working Papers, forthcoming.

\section{Restructuring the healthcare system}

Life expectancy at birth in Slovenia stood at 79.5 years in 2010, almost matching the OECD average. Total health spending is consistent with Slovenia's economic development level (Figure 9). It accounted for $9 \%$ of GDP in 2010, only slightly lower than the OECD average of $9.5 \%$ of GDP. Health spending grew, in real terms per capita, by an average of almost $3.5 \%$ per year against an average growth rate in real GDP per capita of close to $2.5 \%$ between 2000 and 2010 . Yet spending growth was significantly higher in more expensive inpatient care than in less costly outpatient care. 
Figure 9. The relationship between health spending and per capita incomes Thousand USD per capita, $2010^{1}$

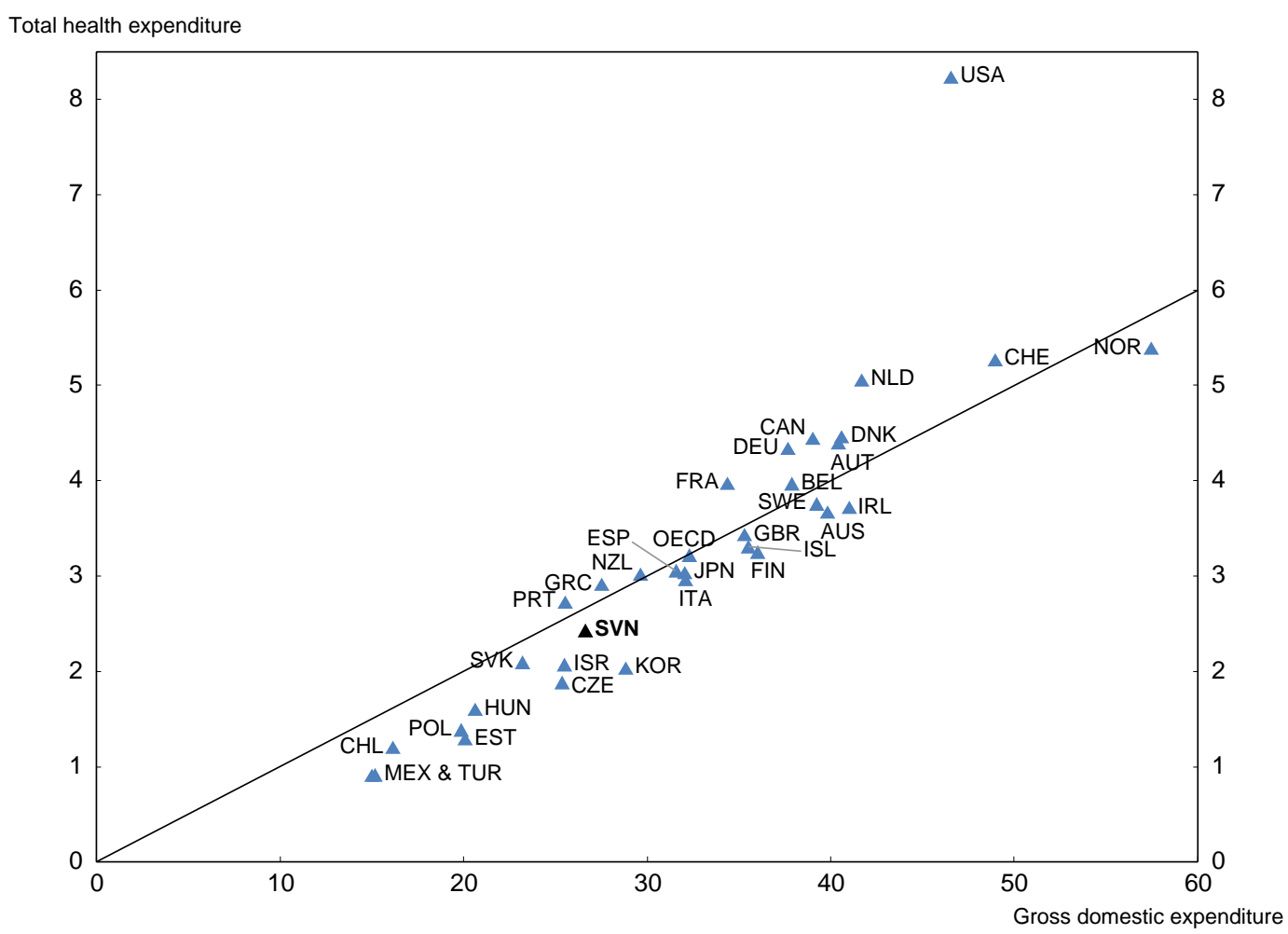

1. Calculated using current purchasing power parities. 2009 for Australia, Israel and Japan; 2008 for Turkey. The OECD aggregate is an unweighted average of data shown.

Source: OECD (2013), OECD National Accounts Statistics and OECD Health Statistics (databases), February.

\section{Strengthening primary care}

There is evidence of a relatively limited supply of health professionals in Slovenia as reflected by a relatively low number of practising doctors (2.4, against an OECD average of 3.1, per 1000 population), practising nurses (8.2, against an OECD average of 8.7, per 1000 population) and one of the lowest ratios of midwives in the OECD (8.7, against 69.8, per 100000 women on average in the OECD). At the same time, the utilisation of the healthcare system in Slovenia is close to the OECD average as gauged by the number of doctor consultations per capita, though it is slightly higher as measured by hospital discharge rates.

The cost effectiveness of generalist-provided primary care is widely recognised, but the allocation of resources is skewed to more costly specialist care. General practitioners (GPs) represent close to $20 \%$ of total doctors in Slovenia, while specialists account for more than $70 \%$ (other doctors explain the remainder). The corresponding shares are around $25 \%$ for GPs and $58 \%$ for specialists in the OECD. As a result, some prevention programmes do not seem to be covered well, despite welcome plans to expand group practices at the primary care level ("reference outpatient clinics") that allow GPs to delegate some tasks to nurses. For instance, screening rates for some types of cancer and influenza vaccination coverage for people above 65 are low by international comparison. Diabetes prevalence is above the OECD average and there is also room to reduce expensive diabetes hospital admission rates. 
An increase in the supply of primary-care doctors would provide scope to strengthen their gatekeeping role and cost-effective prevention in the medium term, though this strategy could boost spending in the short term. Easing the criteria allowing foreign doctors to practice in Slovenia might be one option. In 2011, a shortening of lengthy procedures of recognition of foreign diplomas by about two years was a step in the right direction. Other constraints such as specialty examinations, compulsory internships and, for non-EU candidates, language requirements, would need to be relaxed as well. Another possibility is to improve retention, in particular through better management policies and delayed retirement (OECD, 2008). The authorities should also continue to expand the capacity of medical faculties, set higher quotas for medical students and strive to steer students to disciplines with shortages, such as general practice. Finally, reforming the payment system of GPs by introducing an element of pay-for-performance in the current mixed system of capitation and fee-for-service, would ensure attractive salaries for best performing doctors and provide incentives to a better use of existing capacity. This would encourage expenditure reallocation away from higher levels of care in the medium term.

\section{Rationalising inpatient care}

A third of overall healthcare spending is on inpatient care, slightly above the OECD average of $29 \%$. Overall amenable mortality, which refers to premature deaths that should not occur in the presence of effective and timely care, is just below the OECD average (Gay et al., 2011). With this as a background, there are areas where quality of care in hospital could be improved. The in-hospital case fatality following ischemic and haemorrhagic strokes is one of the highest in the OECD. Screening coverage and survival rates are relatively low for breast and colorectal cancers. Slovenia has also relatively high mortality rates for lung and prostate cancers. At the same time, the penetration of high-technology medical equipment (such as magnetic resonance imaging units and computed tomography scanners) is low. Developing health technology assessment, which is performed at a very basic level, would ensure a cost-effective diffusion and use of medical equipment.

There is scope to improve efficiency in the utilisation of resources allocated to the hospital sector. The number of hospital beds in acute care could be lowered, as occupancy and turnover rates are relatively low, pointing to excess capacity in inpatient care. Indeed, there is room to increase specialisation and adjust the size of hospitals to the needs of individual regions (Ministry of Health, 2011a). The average length of stay in hospital for all causes is shorter than on average across OECD countries, but could still be reduced for some diagnostic categories, such as tuberculosis or diseases of the pancreas (Table 4).

Various efficiency gaps could be tackled by fully phasing in by 2014 the review of the payment per case system based on diagnosis-related groups for acute inpatient care services that has started in 2013. This system, borrowed from the Australian public sector established in the early 2000s, assigns patients into clinically and economically homogenous groups and specifies associated treatment protocols and price schedules. Yet it was neither adapted to the Slovenian case nor updated with new treatment methods prior to the recent amendments, which had been reducing cost efficiency and transparency of the overall system. Indeed, costs could have been recognised arbitrarily and different fees could have been applied for the same diagnosis-related groups in various hospitals (Albreht et al., 2009). 
Table 4. Average length of stay in inpatient and acute care for selected diagnostic categories

Number of days, 2010

\begin{tabular}{lccc}
\hline & Slovenia & OECD $^{1}$ & $\begin{array}{c}\text { Gap } \\
\text { (OECD-SVN) }\end{array}$ \\
\hline Inpatient care & 6.7 & 8.8 & 2.1 \\
Acute care & 5.4 & 6.2 & 0.8 \\
All causes & 6.3 & 7.0 & 0.7 \\
Diagnostic categories where improvements are possible & & \\
Paralytic ileus and intestinal obstruction without hernia & 13.5 & -5.1 \\
Tuberculosis & 29.7 & 24.9 & -4.8 \\
Complications of surgical and medical care, n.e.c. & 12.7 & 9.3 & -3.4 \\
Malignant neoplasm of ovary & 11.7 & 8.4 & -3.3 \\
Diseases of pancreas & 11.8 & 8.6 & -3.2 \\
Pulmonary heart disease and diseases of pulmonary circulation & 11.9 & 9.2 & -2.7 \\
Peptic ulcer & 10.2 & 7.6 & -2.6 \\
Disorders of teeth and supporting structures & 5.7 & 3.2 & -2.5 \\
Other diseases of the digestive system & 9.3 & 7.2 & -2.1 \\
\hline
\end{tabular}

1. The OECD aggregate is an unweighted average of data available and covers 26 countries for inpatient care, 24 for acute care and 21 or 22 countries for all other categories.

Source: OECD (2012), “OECD Health Data: Health care utilisation”, OECD Health Statistics (database).

Finally, more effort is needed to promote ambulatory care. For example, the share of cataract surgeries carried out as day cases in Slovenia was only around 7\% in 2010, compared to over 95\% in many other OECD countries (including Denmark, Estonia, Finland, Spain, Sweden and United Kingdom). Only around $8 \%$ of surgical procedures for inguinal and femoral hernia were carried out on a same-day basis, against more than $50 \%$ for best-performing OECD countries. However, latest government data suggest significant improvements in the share of surgeries carried out as day cases, with those for cataract at $98 \%$ in 2011.

\section{Reforming the financing of health care}

Ageing, higher incomes and cost-increasing technological progress will increasingly strain government budgets. The public sector is the main source of health funding. In 2010 , nearly $73 \%$ of health expenditure was funded by public sources (mainly stemming from contributions to compulsory health insurance), which was around 0.5 percentage point higher than the OECD average. Additional financing of the health system in Slovenia was derived from private voluntary health insurance and out-of-pocket payments, with respective shares in total health expenditure of around $12.5 \%$ and $13 \%$.

The Health Insurance Institute of Slovenia (HIIS) is a single provider of compulsory health insurance and ensures a universal health coverage. However, the system does not cover the full price of all health services and requires co-payments, for instance ranging from about $5 \%$ for the most demanding surgical interventions, to $25 \%$ for most hospital services, and up to $90 \%$ for some medicines. Cost sharing is either through out-of-pocket payments or from voluntary complementary private insurance. The insurance guarantees full co-payment coverage (for all services covered by compulsory health insurance) and almost $95 \%$ of the population subscribes. To avoid cream skimming compensating for differences in risk structure between private insurers, a risk-equalisation scheme was implemented in 2005 based on open enrolment and equal risk premiums, irrespective of individual age, gender and health status.

Private complementary health insurance needs to be reformed to be made more sustainable. The system is voluntary, subscribed by almost $95 \%$ of individuals and based on a risk-equalisation scheme to 
avoid cream skimming compensating for differences in risk structure between private insurers. In 2011, the previous government proposed to abolish the complementary health insurance and beef up the compulsory part, to be paid for by an increase in employees' social security contributions (Ministry of Health, 2011a). These proposals were not implemented, but were motivated by the lack of progressivity (premiums are flat); adverse incentives for providers to boost unnecessary demand combined with a low cost awareness of users (the coverage of co-payments is full); positive externalities for insurers from lower prices of health services negotiated by the HIIS; overall cost of operating the system (a fraction of premiums is used for administrative expenses and profits); and a high level of regulation hindering access of foreign insurance companies to the Slovenian market (which led to a referral of the case to the European Court of Justice).

There is no one health system that performs systematically best in improving the population health status in a cost-effective manner, and therefore a "big bang" approach may not necessarily improve efficiency (OECD, 2010a). Rather, it is how a given system is managed that counts (OECD, 2010b). With this as a background, there are options to reform the complementary health insurance instead of abolishing it. As complementary insurance premiums are flat irrespective of age, this puts the financial situation of the complementary health insurance industry at risk as population ages, potentially leading to insufficient coverage. This problem could be tackled by allowing premium differentiation by age as adopted in a number of countries (OECD, 2004; Thomson and Mossialos, 2009, Table 6). Besides, introducing a fee for some health services, which could not be covered and reimbursed by complementary insurance, would prevent unnecessary care and represent a supplementary tool for cost control for the public purse. There is scope to increase out-of-pocket health expenditure in Slovenia as its burden amounts to slightly above 2\% of final household consumption, and is one percentage point lower than the OECD average (OECD, 2011b). Concerns over rising inequalities in access to care could be addressed by differentiating co-payments according to income levels while ensuring full co-payment coverage for chronically ill people.

Efficiency gains could be obtained in the medium term by involving insurance companies along with the HIIS in the purchasing process of health services. Today, the insurers do not commission services from providers but merely reimburse their clients (Albreht and Klazinga, 2010). Authorising selective contracting, cancelling obligations to contract with all providers, or creating incentives for involvement in preventive care would represent additional policy levers to foster cost-control efforts of insurers. This could promote greater integration of providers within a single organisation, such as the health maintenance organisations in the United States, and thus allow more cost-effective coordination of care (OECD, 2009b).

\section{Reviewing compulsory health insurance}

A reform of compulsory health insurance is also needed to absorb future strains on public expenditure and prevent the practice of shifting a growing part of the burden of paying for health care onto complementary insurers. This is also a concern in a period of economic downturn and lower cyclical payroll contributions while the HIIS is subject to a balanced budget constraint. There is room to rationalise the public benefit basket by reducing the reimbursement rate or delisting certain less medically necessary services, such as spa treatments, non-emergency ambulance transportation or less clinically effective medicines. Moreover, charging working students (as was planned in the mini jobs legislation rejected by referendum in 2011) as discussed in the education chapter in the 2011 Economic Survey of Slovenia (OECD , 2011c) and increasing the contribution rate of pensioners would broaden the tax base and increase resources. While the contribution rate for health insurance of employees is $13.45 \%$ of their gross income, with $7.09 \%$ contributed by employers and $6.36 \%$ by employees, pensioners are subject to a rate of only $5.96 \%$ of their gross pension.

There is also scope to reduce the expenditure on pharmaceuticals and the authorities have implemented some measures and are considering further cost-cutting in this area (Ministry of Health, 2011b). These notably include reductions in the prices of original (branded) pharmaceuticals negotiated by 
the HIIS with producers, tighter reference prices for mutually interchangeable medicines, unification of the prices for generics and original pharmaceuticals with expired patent protection, unification of inpatient and outpatient pharmaceuticals, and stricter supervision of advertising.

Slovenia allocates more than $4 \%$ of its total health expenditure on administration and operation of health insurance funds, which is above the OECD average of $3 \%$. While higher costs could be partly due to a multi-payer insurance model, when compared to countries with similar institutions, they are lower than in Belgium (5\%), or France and the United States (7\%), but higher than in Australia and Canada (less than $4 \%$ ). Indeed, the administrative and management costs could be reduced by avoiding mixing the financing of secondary and tertiary activities, permitting a greater autonomy in resource management of public healthcare providers, and rationalising the number of branch offices of the HIIS (Ministry of Health, 2011b).

\section{Rationalising education}

Despite relatively good educational outcomes and the capacity of the Slovenian education system to equip the labour force with relevant skills, there is significant scope for a more efficient use of public resources. Recent plans of the authorities to reform the education system go some way towards the policy priorities identified in the education chapter in the 2011 Economic Survey of Slovenia (OECD, 2011c; Republic of Slovenia, 2012a,b).

\section{Streamlining pre-school and compulsory education}

The costs of providing early childhood education and care are high, notably due to low child-teacher ratios, while there is excess demand in smaller towns. Moreover, average class size in primary and lower secondary education is low and the ratio of students to teaching staff are below the OECD average in preprimary and lower secondary education (OECD, 2012). Empirical analysis suggests that raising pupilteacher ratios and increasing class sizes would not negatively affect the quality or undermine the performance of compulsory education (Sutherland and Price, 2007). To this end, some of the schools and school districts need to be merged and the schools linked into clusters. This would allow a more effective use of staff, but could also increase population density in some areas. The authorities considered increasing teaching obligations and setting up unified school districts along with the adoption of a floor for the minimum number of pupils in a classroom. This would have led to lower costs due to a merger of some schools.

However, the reform proposals have met with strong opposition from teachers' trade unions, who expressed fears that such changes could undermine the quality of the education system and threatened to challenge the proposals in a referendum. This could have blocked the introduction of broader fiscal consolidation measures in mid-2012. Therefore, even though some schools have been merged, the implementation of the planned rationalisation steps had been largely postponed and, more recently, officially suspended.

\section{Boosting the efficiency of tertiary education}

Additional efficiency gains could stem from measures affecting higher education, all the more so as resources devoted to higher education, as measured by spending per student, are relatively low by international comparison. The combination of low student fees, access to generous subsidies and benefits, and preferential tax and regulatory treatment of student work lead to low completion rates and excessively long effective study durations (close to six years on average at the undergraduate level in 2011). Making eligibility to in-study benefits conditional on adequate progress of studies and introducing universal tuition fees along with means-tested grants and loans with income-contingent repayment would improve spending efficiency and tackle biased incentives to remain in the education system for too long. 
The authorities plan to cancel the financing of student repetition and, more generally, make the funding conditional on effective enrolment and completion rates. There are also plans to shorten the excessive average duration of studies by eliminating a so-called one year period of graduation preparation in the first cycle of studies (undergraduate three years) to complete missing examinations. On the other hand, a law that would have reduced the attractiveness of student work (OECD, 2011c) was rejected by referendum in April 2011, though a related compulsory fee paid by employers was hiked from $14 \%$ to $25 \%$ in 2012 and the generosity of tax allowances granted to students has been cut by a quarter. Another law, adopted in May 2011, permits recovery of part of costs from students who extend their studies beyond normal study durations.

\section{Containing pressures on future public expenditure}

\section{Overhauling the pension system}

\section{The pension system is unsustainable}

Slovenia has one of the least sustainable pension systems in the OECD, reflecting a combination of pension generosity and population ageing as assessed in the 2009 and 2011 Economic Surveys of Slovenia (OECD, 2009c; 2011c). The share of public pension expenditure is currently around 11\% of GDP and, prior to the adoption of the recent pension reform, was projected to rise by slightly more than seven percentage points of GDP by 2060, with most of the change likely to occur after 2030 (European Commission, 2012b). The effective retirement age is low, at nearly 62 for men and $581 / 2$ for women against an OECD average of close to 64 and $62 \frac{1}{2}$, respectively. The old-age dependency ratio, the ratio of people aged 65 and over to the population aged 20-64, is projected to increase from $26 \%$ in 2010 to $63 \%$ in 2060 . At the same time, the working-age population (aged 15 to 64) as a share of total population is projected to fall by almost 15 percentage points by 2060 , compared with a drop of nearly 11 percentage points for the European Union as a whole.

A parametric reform of the first (defined benefit) pension pillar was prepared by the previous government, and adopted by parliament, but voted down in June 2011 in a referendum. As discussed in the 2011 Economic Survey of Slovenia (OECD, 2011c), the aim was to increase the statutory retirement age to 65 and the minimum retirement age to 60 for both men and women, boost financial incentives to work longer, lengthen the period for the calculation of the pension base, and introduce a partial indexation of pensions to inflation (and not only to wage growth). However, despite being a step in the right direction, the budgetary impact of the reform would have been insufficient to put long-term public finances on a sustainable footing. Indeed, the reform would have mainly postponed the projected rise in public expenditure by around seven years and reduced its expected increase by approximately 2.5 percentage points of GDP by 2060.

Using the 2011 failed pension reform as a starting point, the current government negotiated with social partners and successfully adopted a new reform of the first pillar in December 2012. The main differences with the previous reform include a somewhat longer minimum insurance period (40 years instead of 38) for women to retire at the age of 60, tighter conditions to get a full pension with 40 years of contributions, slightly lower accrual rates, and a less generous indexation of pensions with a higher weight of inflation ( $40 \%$ instead of $30 \%)$ and a correspondingly lower weight of wage growth. On the other hand, the pension base was less extended than foreseen in 2011 - raising from 18 to 24 (instead of 27) best consecutive years of contributions. Overall, the effective retirement age is expected to rise by close to two and a half years to 62 for women and by around nine months to 63 for men by 2020 . However, the reform will stabilise public spending on pensions as a share of GDP (at around $11 \%$ ) only until 2020, with the ratio projected to increase thereafter by 5 to 6 percentage points of GDP by 2060 . 


\section{Additional reforms are needed}

A new reform package with more comprehensive measures is required to significantly cut the longterm financing needs and raise the second lowest labour force participation rate of older workers in the OECD (Figure 10). This can be done by raising the pension eligibility age (both statutory and minimum) and required contributory periods, and indexing further increases in pension parameters to gains in life expectancy. For instance, with a legal retirement age at 65 in 2020, projected life expectancy at 65 would widen by about four years until 2060 (European Commission, 2012b). In this perspective, it is unfortunate that public sector employees who reached the statutory retirement age were requested to retire as part of the fiscal consolidation programme implemented in mid-2012.

Figure 10. Labour force participation rate of older workers is low

Per cent, age 55-64, 2011

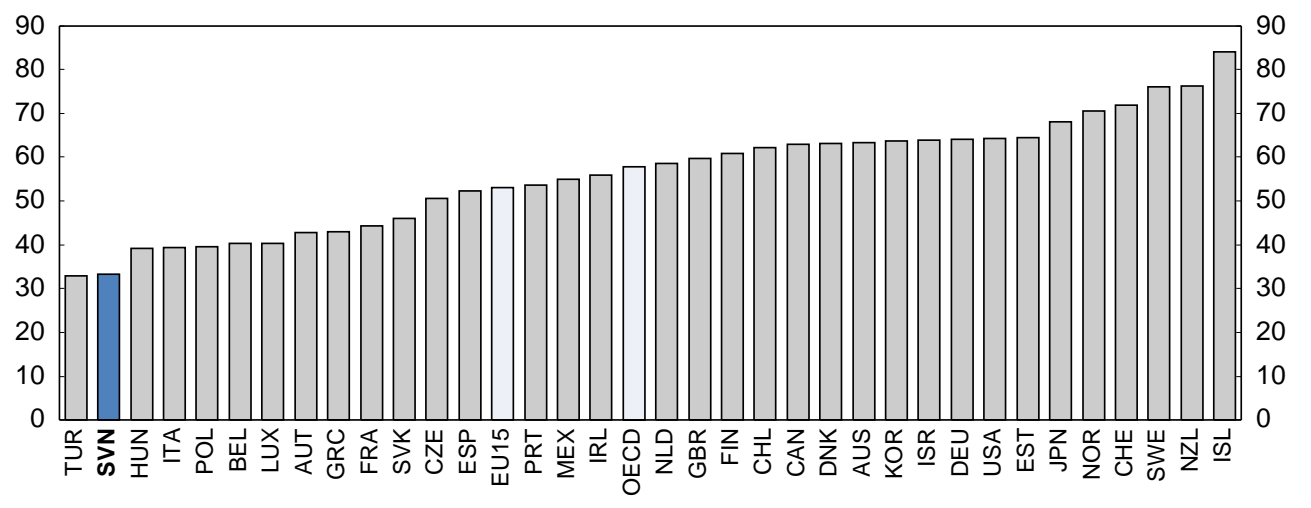

Source: OECD (2013), OECD Employment and Labour Market Statistics (database), March.

Longer work activity could also be favoured by reducing the implicit tax on continued work at older ages (Figure 11). The penalty (bonus) for early (deferred) retirement of $3.6 \%(4 \%)$ per year pencilled in to the recent pension reform may encourage workers to retire early as it is below the actuarially neutral level of around 6-8\% estimated for OECD countries (Queisser and Whitehouse, 2006). Recent amendments of the pension system have cut early retirement options, though they also allow for lowering the retirement age depending on the number of children (by 6 months for one child, 16 months for two children, 26 months for three, 36 months for four, and 48 months for five or more children), military service and early career starts. Conditions to retire early could also be tightened for numerous special pension regimes (policemen, firemen, pilots, miners, etc.). More generally, reducing the gap between the statutory (full pension) and minimum (partial pension) retirement ages would influence the actual behaviour of labour supply and demand through stronger incentives for life-long learning or better social perception of work capability at older ages.

The authorities could also consider further diminishing the generosity of the net replacement rate. Once the new pension reform is fully phased in the benefit ratio for 40 years of contributions is expected to reach $59 \%$ of the pension rating base, for men and women respectively. Pensioners in Slovenia are also entitled to family allowances and those above 65 are eligible for a seniority allowance (OECD, 2011d), which may significantly increase their replacement rate. Further extending the base period for the calculation of the pension rating base would lead to a reduction in the replacement rate and many OECD countries are moving to a lifetime concept to assess pensions. Moreover, effective accrual rates could be cut by lowering rates at which benefits accrue and/or diminishing the adjustment of past earnings to the time of retirement for changes in standards of living. For instance, in Belgium, France, and Spain past 
earnings are valorised in line with prices rather than average-earnings growth, while Finland and Portugal use a mix of prices and earnings.

Figure 11. Implicit tax on continued work at older ages ${ }^{1}$

Per cent of average worker earnings, $2009^{2}$

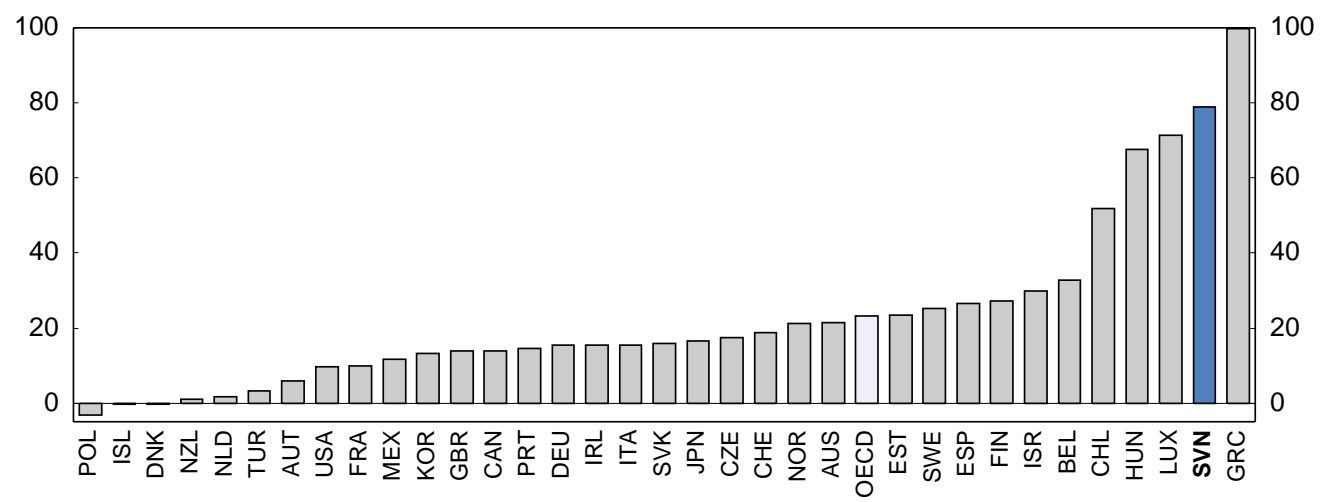

1. Implicit tax on continued work in regular old-age pension system, for 60 year-olds. For methodology see R. Duval (2003), "The Retirement Effects of Old-Age Pension and Early Retirement Schemes in OECD Countries", OECD Economics Department Working Papers, No. 370.

2. 2010 for France.

Source: OECD (2013), Economic Policy Reforms 2013: Going for Growth.

Benefit indexation rules could be further reviewed by shifting to a combination of prices and wages with equal weights (as, for example, in Estonia, Hungary, Slovak Republic and Switzerland) or taking into account only the effect of prices (as, for instance, in France, Japan, Spain, United Kingdom or United States). The generosity of indexation has been challenged by the crisis. It was reduced to half and a quarter of nominal wage growth in 2010 and 2011, respectively. The indexation of pensions was frozen in 2012 and, as part of fiscal consolidation, only a $0.1 \%$ increase is foreseen in 2013.

Ensuring pension adequacy for the most vulnerable is another challenge. Old-age poverty rates are close to $20 \%$ in Slovenia, partly as a result of a low average insurance period of 32 years to get a pension, with a minimum of 15 years of contributions to retire at the age of 65 . This calls for beefing up socialassistance for low-income pensioners before pension adequacy increases with the recommended raise in the minimum insurance period to receive a pension. The recent creation of a consultative pension register should enhance transparency of accrued pension rights and help reduce poverty risks in retirement.

\section{Enhancing long-term care}

\section{Spending on long-term care is low but likely to increase significantly}

At close to $1.3 \%$ of GDP in 2010, total spending on long-term care (LTC) in Slovenia is below the OECD average of $1.5 \%$ of GDP. The public share is predominant and private spending on LTC accounts for around $0.3 \%$ of GDP, as much as across the OECD. Almost $5 \%$ of the population over the age of 65 receive LTC in the institutional sector and, as in many other OECD countries, the majority of LTC cost originates from that setting.

LTC still accounts for a relatively small share of GDP compared with age-related spending on health and pensions, but population ageing is likely to put pressure for further public spending on LTC. The greater longevity of individuals can be expected to increase the number of severely disabled. The share of people aged 80 and over will triple to reach $12 \%$ in Slovenia and become one of the highest across the 
OECD by 2050 (Colombo et al., 2011). As in other OECD countries, demand for LTC services is also likely to increase because of declining family size and ties, growing participation of women in the formal labour market, and rising incomes. The latter factor should stimulate demand for better quality and technologically more sophisticated LTC services. In parallel, the ageing process should push up wage costs by reducing the potential supply of formal and informal carers as the working age population is projected to shrink by $20 \%$ in Slovenia by 2060 (European Commission, 2012b). Overall, public LTC as a share of GDP is projected to at least double by 2060, according to the European Commission.

\section{Reorganising long-term care and developing financing models is necessary}

As in many OECD countries, LTC is a fragmented sector in Slovenia. There are many stakeholders involved in the provision, management and organisation of LTC and several social security laws regulate the sector. LTC in Slovenia is targeted to people over 65, the disabled and the chronically ill. It is based on non-income-tested cash benefits and income-tested benefits in kind (the former cannot be chosen in lieu of the latter by care recipients), provided by health care and/or social services in the form of residential or home care. Cash benefits and residential care are organised centrally while home care services are provided on a local level. Overall, the current system of LTC appears complex and fragmented, with weak coordination between different services, and is insufficiently developed to meet actual and future needs (Prevolnik Rupel et al., 2010).

A new reform has been in preparation since 2005, but has still not been adopted. The objective is to combine LTC services and benefits in an integrated system (by introducing case managers and individual plans and rights for LTC users), put a greater emphasis on the development of home care, and establish new forms of financing LTC. The funding issue has been debated as regards the appropriate tax base for public LTC insurance and the opportunity to create an additional private insurance (Dominkuš and Gracar, 2011). Slovenia does not have a specific LTC funding system: social security contributions on health, pension and disability represent the major source of public funding, complemented by general tax revenues and a local tax for care for disabilities.

For the provision and financing of LTC, Slovenia could look to the experience of other OECD countries (Colombo et al., 2011). Uncertainty concerning the need for LTC services suggests that pooling related financial risks is more efficient in ensuring high and equitable access to care than relying solely on out-of-pocket payments. There has been convergence in the OECD towards adopting a collectively financed system that provides a universal eligibility for a basic package of care, though with differences regarding its generosity (Colombo et al., 2011). However, even in universal systems it is desirable to take into account the individual's ability to pay through income and/or asset means tests and target care benefits to those with the greatest needs.

In Slovenia, such a system of "targeted universalism" could be financed with compulsory public insurance, with contributions levied on the working-age population and retirees, as implemented in Germany and currently planned by the authorities. The levy is expected to combine current sources of financing of LTC, which would increase the transparency of the new system. By extending the tax base beyond the working-age population in the face of population ageing, this would mitigate the increase in labour costs, better pool financing across generations, and ensure funding stability. Increasing user costsharing for LTC would also help to contain public spending and mitigate moral hazard risk. For instance, users should be charged for the cost of board and lodging in nursing homes by drawing on accumulated savings and personal wealth, as otherwise they may prefer institutionalisation over receiving care at home.

Developing private LTC insurance would also alleviate pressure on public expenditure, but insurance market failures linked to asymmetric information and consumer's difficulty in forward planning are an obstacle. Automatically enrolling people in voluntary funding schemes with opting-out options as in 
Singapore would be an innovative solution (Colombo et al., 2011). Alternatively, private LTC insurance could also be made fully compulsory (Dominkuš and Gracar, 2011). Such a system, currently considered by the authorities, could be quickly introduced in Slovenia due to the potential synergies with the widespread availability of voluntary private health insurance.

\section{Developing home care to mitigate growing cost pressure}

Seeking better value for money could mitigate pressure on LTC expenditure. Encouraging home and community care, which also has the advantage of being preferred by users, is key. Incentives to use home care in Slovenia are distorted by higher user cost-sharing and lower rights for services than in institutional settings (Prevolnik Rupel et al., 2010). Creating a level playing field for accessibility to health services is thus necessary. Tighter regulations for admissions to institutional care, for instance as introduced in the Czech Republic and Finland, would also help in developing alternative services. However, institutional care can prove more cost-effective than home care in some cases, in particular for users in remote areas and those requiring intense care and supervision.

To support rebalancing LTC away from institutional care towards home and community-based care, policies in OECD countries also provide financial incentives for care recipients or carers. Yet increasing reliance on active family carers requires measures facilitating the combination of work and caring duties, for instance through flexible work schemes, and ensuring an appropriate level of compensation. In Slovenia, caregivers living in the same household as the insured care recipient are entitled to a compensation of only 7 (exceptionally 14) days a year, which is low and would need to be expanded.

Municipalities are meant to cover at least $50 \%$ of the price of the home care services, but small local authorities are encountering growing difficulties to do so. All but one municipality grants concessions for carrying out home care to a single provider, most often a public institution (Prevolnik Rupel et al., 2010). Alternatively, giving patients greater autonomy to organise their own care with a system of vouchers, as adopted in the Nordic countries, could enhance competition among home care providers and lower the price of services and municipalities' expenditure. At the same time, rewarding municipalities financially for reduced institutionalisation rates would prevent incentives to redirect patients towards centrally funded and more expensive institutional care. 


\section{Box 3. Policy recommendations to restructure welfare spending}

\section{Mitigating the dispersion of incomes}

- Continue to reduce high-income earners' eligibility for family benefits and strengthen means testing of education-related benefits.

- $\quad$ Ensure pension adequacy for the most vulnerable by raising the minimum insurance period of fifteen years.

\section{Rationalising cash transfers}

- Continue to gradually cut the combined generosity of unemployment benefits, social assistance and other transfers for the unemployed and inactive persons.

- $\quad$ Enhance support for unemployed and streamline administrative costs by merging the Employment Service of Slovenia and the Centres for Social Work.

\section{Restructuring publicly provided services on health and education}

- $\quad$ Reduce costs by increasing pupil-teacher ratios in pre-primary and lower secondary education and class sizes in primary and lower secondary education.

- Introduce universal tuition fees along with means-tested grants and loans with income-contingent repayments to boost spending efficiency.

- $\quad$ Further rationalise the public health benefit basket, shifting from inpatient to ambulatory care and boosting the supply of general practitioners.

\section{Continuing the reform of the pension system}

- $\quad$ Further extend the pension eligibility age and contributory periods and index their further increases to gains in life expectancy. Phase out the gap between statutory and minimum retirement ages and effectively close other pathways into early retirement, including for special pension regimes.

- Consider further reducing the replacement rate by extending the pension rating base and lowering the effective accrual rates. Increase the weight of inflation in the pension indexation rule.

Improving the financing of health care

- $\quad$ Broaden the tax base of compulsory health insurance to working students and align the health insurance contribution of pensioners with the standard contribution of employees.

- $\quad$ Permit some increase in premiums with age of complementary health insurance.

\section{Enhancing long-term care}

- Implement reform plans of the financing of long-term care by setting up a specific funding system levied on the working-age population and pensioners.

- $\quad$ Develop home care by creating level playing field with institutional care in the accessibility to health services and giving patients more freedom to organise their own care with a system of vouchers. 


\section{Bibliography}

Albreht, T. and N. Klazinga (2010), "Balancing Equity and Efficiency Through Health Care Policies in Slovenia During the Period 1990-2008", Zdrav Var, No. 49.

Albreht, T., E. Turk, M. Toth, J. Ceglar, S. Marn, R. Brinovec and M. Schäfer (2009), "Slovenia - Health System Review", Health Systems in Transition, Vol. 11, No. 3, European Observatory on Health Systems and Policies.

Bouis, R., O. Causa, L. Demmou, R. Duval and A. Zdzienicka (2012), "The Short-Term Effects of Structural Reforms: An Empirical Analysis", OECD Economics Department Working Papers, No. 949, OECD Publishing, http://dx.doi.org/10.1787/5k9csvk4d56d-en.

Colombo, F., A. Llena-Nozal, J. Mercier and F. Tjadens (2011), Help Wanted? Providing and Paying for Long-Term Care, OECD Publishing, http://dx.doi.org/10.1787/9789264097759-en.

Dominkuš, D. and I. Gracar (2011), "Closing the Gap - In Search for Ways to Deal with Expanding Care Needs and Limited Resources", Comment Paper, Peer Review in Social Protection and Social Inclusion and Assessment in Social Inclusion, October.

European Commission (2012a), Fiscal Sustainability Report, European Economy, No. 8.

European Commission (2012b), The 2012 Ageing Report. Economic and Budgetary Projections for the 27 EU Member States (2010-2060), European Economy, No. 2.

Gay, J.G., V. Paris, M. Devaux and M. de Looper (2011), "Mortality Amenable to Health Care in 31 OECD Countries: Estimates and Methodological Issues", OECD Health Working Papers, No. 55, OECD Publishing, http://dx.doi.org/10.1787/5kgj35f9f8s2-en.

Hribernik, M. and R. Kierzenkowski (2013), "Assessing the Efficiency of Welfare Expenditure in Slovenia with Data Envelopment Analysis", OECD Economics Department Working Papers, OECD Publishing, forthcoming.

Joumard, I., M. Pisu and D. Bloch (2012), "Less Income Inequality and More Growth - Are they Compatible? Part 3. Income Redistribution via Taxes and Transfers Across OECD Countries", OECD Economics Department Working Papers, No. 926, OECD Publishing, http://dx.doi.org/10.1787/5k9h296b1zjf-en.

Kump, N., B. Majcen and M. Čok (2011), “Assessing the Benefits Reform in Slovenia Using a Microsimulation Approach", Institute for Economic Research, unpublished document.

Mattina, T. and V. Gunnarsson (2007), "Budget Rigidity and Expenditure Efficiency in Slovenia", IMF Working Papers, No. 07/131, International Monetary Fund.

Meghir, C. and D. Phillips (2010), "Labour Supply and Taxes", The Mirrlees Review, Institute for Fiscal Studies.

Ministry of Health (2011a), Health Care System Upgrade by 2020, Republic of Slovenia, February.

Ministry of Health (2011b), "Measures Foreseen in Slovenia in a Strategy of Upgrading Health care System by 2020", unpublished document.

OECD (2012), "How Are Countries Around the World Supporting Students in Higher Education?", Education Indicators In Focus, No. 2, OECD Publishing, http://dx.doi.org/10.1787/5k9fd0kd59f4en.

OECD (2011a), Divided We Stand. Why Inequality Keeps Rising, OECD Publishing, http://dx.doi.org/10.1787/9789264119536-en. 
OECD (2011b), Health at Glance 2011: OECD Indicators, OECD Publishing, http://dx.doi.org/10.1787/health_glance-2011-en.

OECD (2011c), OECD Economic Surveys: Slovenia 2011, OECD Publishing, http://dx.doi.org/10.1787/eco_surveys-svn-2011-en.

OECD (2011d), Pensions at a Glance 2011: Retirement-income Systems in OECD and G20 countries, OECD Publishing, http://dx.doi.org/10.1787/pension_glance-2011-en.

OECD (2010a), Health Care Systems: Efficiency and Policy Settings, OECD Publishing, http://dx.doi.org/10.1787/9789264094901-en.

OECD (2010b), Value for Money in Health Spending, OECD Health Policy Studies, OECD Publishing, http://dx.doi.org/10.1787/9789264088818-en.

OECD (2009a), OECD Reviews of Labour Market and Social Policies: Slovenia 2009, OECD Publishing, http://dx.doi.org/10.1787/9789264068995-en.

OECD (2009b), Achieving Better Value for Money in Health Care, OECD Publishing,

OECD (2009c), OECD Economic Surveys: Slovenia 2009, OECD Publishing, http://dx.doi.org/10.1787/eco_surveys-svn-2009-en .

OECD (2008), The Looming Crisis in the Health Workforce: How Can OECD Countries Respond?, OECD Health Policy Studies, OECD Publishing, http://dx.doi.org/10.1787/9789264050440-en.

OECD (2004), Towards High-Performing Health Systems, The OECD Health Project, OECD Publishing, http://dx/doi.org/10.17787/9789264015562-en.

Prevolnik Rupel, V., M. Ogorevc and B. Majcen (2010), "The Long-Term Care System for the Elderly in Slovenia", ENEPRI Research Report,No. 87, European Network of Economic Policy Research Institutes.

Queisser, M. and E.R. Whitehouse (2006), "Neutral or Fair? Actuarial Concepts and Pension-System Design", OECD Social, Employment and Migration Working Papers, No. 40, OECD Publishing, http://dx.doi.org/10.1787/351382456457.

Republic of Slovenia (2012a), Stability Programme, 2012 Update, April.

Republic of Slovenia (2012b), National Reform Programme 2012-2013, April.

Stovicek, K. and A. Turrini (2012), "Benchmarking Unemployment Benefit Systems", European Economy - Economic Papers, No. 454, European Commission.

Stropnik, N. (2011), "Improving the Efficiency of Social Protection", Comment Paper, Peer Review in Improving the Efficiency of Social Protection, Portugal, November.

Sutherland, D. and R. Price (2007), "Linkages Between Performance and Institutions in the Primary and Secondary Education Sector", OECD Economics Department Working Papers, No. 558, OECD Publishing, http://dx.doi.org/10.1787/170826717775.

Thomson, S. and E. Mossialos (2009), Private Health Insurance in the European Union, Final report prepared for the European Commission, London School of Economics and Political Science. 


\section{WORKING PAPERS}

The full series of Economics Department Working Papers can be consulted at www.oecd.org/eco/workingpapers/

1060. The economics of civil justice: new cross-country data and empirics by G. Palumbo; G. Giupponi; L. Nunziata and J. Mora-Sanguinetti (forthcoming)

1059. Banks' restructuring and smooth deleveraging of the private sector in Slovenia (June 2013) by Olena Havrylchyk

1058. Assessing the efficiency of welfare spending in Slovenia with data envelopment analysis (June 2013) by Matevz Hribernik and Rafał Kierzenkowski

1057. Policy determinants of school outcomes under model uncertainty: evidence from South Africa (June 2013) by Thomas Laurent, Fabrice Murtin, Geoff Barnard, Dean Janse van Rensburg, Vijay Reddy, George Frempong and Lolita Winnaar

1056. Improving education quality in South Africa

(June 2013) by Fabrice Murtin

1055. The 90\% public debt threshold: the rise and fall of a stylised fact

(June 2013) by Balázs Égert

1054. Challenges to sustain Poland's growth model

(June 2013) by Balázs Égert and Rafał Kierzenkowski

1053. Reforming agriculture and promoting Japan's integration in the world economy

(May 2013) by Randall S. Jones and Shingo Kimura

1052. Inequality and poverty in the United States: public policies for inclusive growth

(May 2013) by Oliver Denk, Robert Hagemann, Patrick Lenain and Valentin Somma

1051. Fiscal federalism and its impact on economic activity, public investment and the performance of educational systems

(May 2013) by Hansjörg Blöchliger, Balázs Égert and Kaja Fredriksen

1050. Restoring Japan's fiscal sustainability

(May 2013) by Randall S. Jones and Satoshi Urasawa

1049. Measuring total factor productivity at the firm level using OECD-ORBIS

(May 2013) by Peter Gal

1048. A projection method for public health and long-term care expenditures

(June 2013) by Christine de la Maisonneuve and Joaquim Oliveira) Martins

1047. R\&D, patenting and growth: the role of public policy

(May 2013) by Ben Westmore

1046. Knowledge-based capital, innovation and resource allocation

(May 2013) by Dan Andrews and Chiara Criscuolo 
1045. Reforms for a Cleaner, Healthier Environment in China (April 2013) by Sam Hill

1044. Making the tax system less distortive in Switzerland (April 2013) by Andrés Fuentes

1043. The determinants of informality in Mexico's states (April 2013) by Sean M. Dougherty and Octavio Escobar

1042. Legal reform, contract enforcement and firm size in Mexico (April 2013) by Sean M. Dougherty

1041. Improving the economic situation of young people in France (April 2013) by Hervé Boulhol Améliorer la situation économique des jeunes en France (avril 2013) par Hervé Boulhol

1040. Improving employment prospects for young workers in Spain (April 2013) by Anita Wölfl

1039. Youth labour market performance in Spain and its determinants - a micro-level perspective (April 2013) by Juan J. Dolado, Marcel Jansen, Florentino Felgueroso, Andres Fuentes and Anita Wölfl

1038. The efficiency and equity of the tax and transfer system in France (April 2013) by Balázs Égert

Efficacité et équité du système de prélèvements et de transferts en France (avril 2013) par Balázs Égert

1037. Income inequality and poverty in Colombia. Part 2. The redistributive impact of taxes and transfers (April 2013) by Isabelle Joumard and Juliana Londoño Vélez

1036. Income inequality and poverty in Colombia. Part 1. The role of the labour market (April 2013) by Isabelle Joumard and Juliana Londoño Vélez

1035. Policy options to durably resolve euro area imbalances (March 2013) by Yvan Guillemette and Dave Turner

1034. Labour market, welfare reform and inequality in the United Kingdom

(March 2013) by Christophe André, Clara Garcia, Giulia Giupponi and Jon Kristian Pareliussen

1033. Work incentives and Universal Credit - reform of the benefit system in the United Kingdom (March 2013) by Jon Kristian Pareliussen

1032. Strengthening social cohesion in Luxembourg: making efficiency and equity go hand in hand (March 2013) by Jean-Marc Fournier and Clara Garcia

1031. The price of oil - Will it start rising again?

(March 2013) by Jean-Marc Fournier, Isabell Koske, Isabelle Wanner and Vera Zipperer 